\title{
Is Historical Cost Accounting a Panacea? Market Stress, Incentive Distortions, and Gains Trading
}

\author{
Andrew Ellul \\ Indiana University, ECGI and CSEF \\ Chotibhak Jotikasthira \\ University of North Carolina \\ Christian T. Lundblad \\ University of North Carolina \\ Yihui Wang \\ Chinese University of Hong Kong
}

April 2012

\begin{abstract}
We provide new empirical evidence concerning the contentious debate over the use of historical cost versus fair value accounting in regulating financial institutions. These accounting rules, through their interactions with capital regulation, alter financial institutions' optimal portfolio choice and trading behavior. The insurance industry provides a natural laboratory in which to explore these interactions. First, there exist significant differences in regulatory accounting rules; life insurers have greater flexibility to hold speculative-grade instruments at historical cost than property and casualty insurers. Second, within an insurer's investment portfolio, detailed data are available on transactions, positions, and, most importantly, the regulatory accounting treatment for each security. When faced with severe downgrades among their holdings in asset-backed securities (ABS), life insurers largely continue to hold the downgraded securities at historical cost and instead selectively sell their corporate bond holdings with the highest unrealized gains, inducing significant price declines. This is particularly true for life insurers facing regulatory capital constraints and with high ABS exposures. This behavior is largely absent among property and casualty insurers; they instead disproportionately sell their re-marked ABS holdings. Historical cost accounting creates an altered incentive environment in which constrained financial institutions sell assets to realize gains. Insofar as this behavior transmits shocks across potentially unrelated markets, historical cost accounting is not a panacea.
\end{abstract}

JEL classifications: G11; G12; G14; G18; G22

Keywords: Regulation; Mark to market; Historical cost accounting; Gains trading; Fire sales; Asset-backed securities (ABS); Corporate bonds; Insurance companies

Acknowledgments: We are grateful for comments received from Utpal Bhattacharya, Dirk Black, Mike Burkart, Scott Harrington, Cam Harvey, Tim Jenkinson, Sreenivas Kamma, Peter Kondor, Wayne Landsman, Mark Lang, Christian Leuz, Martin le Roux, Dong Lou, Ed Maydew, Marco Pagano, Lubos Pastor, Chester Spatt, Dimitri Vayanos, James Wahlen, and participants in seminars at the 2012 Adam Smith Corporate Finance Conference at Oxford University, Chinese University of Hong Kong, Duke University, Imperial College London, Indiana University, London School of Economics and University of North Carolina (Accounting), and University of Warwick. We are especially grateful to Robert Hartwig of the Insurance Information Institute for several detailed discussions. This research was conducted, in part, while Lundblad was visiting the Einaudi Institute for Economics and Finance in Rome, Italy. Wang acknowledges the financial support from Rega Technologies Limited. 


\section{Introduction}

This paper explores the trading incentives of financial institutions induced by the interaction between regulatory accounting rules and capital requirements. The theoretical literature (see, for example, Allen and Carletti (2008), Plantin, Sapra and Shin (2008), and Sapra (2008)) argues that mark-to-market (MTM), or fair value, accounting leads to the forced selling of assets by financial institutions during times of market stress, resulting in a downward spiral of liquidity and prices and potential contagion effects for other markets. In contrast, these authors contend that historical cost accounting (HCA) may avoid fire sales and contagion effects. ${ }^{1}$ This paper challenges this view by providing new empirical evidence that HCA, along with regulatory capital requirements, induces an altered incentive to "gains trade" where, in order to shore up capital, an institution selectively sells otherwise unrelated assets with high unrealized gains. Critically, it is important not to consider the accounting treatment in isolation, but rather how the different treatments interact with capital regulations (Heaton, Lucas, and McDonald (2010)) to influence financial institutions' trading incentives (Laux and Leuz (2009, 2010)).,3

The role of MTM during the recent financial crisis has generated an intense debate. The accounting rules followed by financial institutions may appear to simply be an issue of measurement and, in frictionless markets, free of any impact on economic fundamentals. However, when markets are illiquid and trading frictions elevated, financial assets may temporarily trade at market prices that are well below fundamental values (Duffie (2010), AFA Presidential Address). In such an environment, write-downs (and the associated deterioration of financial institutions' asset values) will lead to an erosion of their capital base, potentially forcing the liquidation of some assets. Allen and Carletti (2008) argue that in such a market environment, HCA will avoid fire sales because financial institutions would not suffer from a deterioration of their asset valuations in the first place. Plantin, Sapra and Shin (2008) also argue that MTM

\footnotetext{
${ }^{1}$ This is a view that has received support from the banking industry as well. In a letter to the SEC in September 2008, the American Bankers Association was of the opinion that, among several factors that led to the financial crisis, "one factor that is recognized as having exacerbated these problems is fair value accounting."

${ }^{2}$ Carey (1994) finds some evidence of gains trading by banks during 1979-1992. He finds that, at the bank level, most banks appear to gains trade to realize earnings as they appear (snacking) or to smooth earnings over time; very few try to manage tax liabilities or regulatory capital. See also Scholes, Wilson, and Wolfson (1990). Our paper differs from Carey (1994) and Scholes et al. (1990) in that we investigate gains trading at the security level, as opposed to the aggregate portfolio level, which allows us to identify gains trading from other trading motives.

${ }^{3}$ Bleck and Liu (2007) theoretically examine, in a signaling framework, the economic consequences of MTM and HCA. They show that HCA may distort management's incentives, and in some cases, may induce a behavior similar to "gains trading" in our paper when the management tries to signal good project quality to the market.
} 
generates inefficiencies because it injects excessive volatility in prices that naturally degrades their information content and leads to sub-optimal decisions by financial institutions.

HCA may also engender inefficiencies as financial institutions, under HCA, have an incentive to engage in selective asset sales aimed at the early realization of earnings (see Laux and Leuz (2009) for a discussion of the gains trading incentive under HCA). Indeed, Plantin, Sapra and Shin (2008) recognize that HCA is not immune to these inefficiencies in normal times. In this paper, we focus on the implications of this trading incentive and its impact on financial institutions' trading behavior during times of market stress. Below, we argue that it is precisely these times that financial institutions have the highest need to realize gains in order to improve capital positions.

We argue that the crucial issue in the debate surrounding the accounting treatment of financial assets and its impact on financial institutions during periods of market stress relates to the interaction between the accounting regime and the institutional framework, specifically regulatory capital requirements. To focus ideas, consider a financial institution that invested heavily in AssetBacked Securities (ABS) in the years leading up to the financial crisis. The severe downgrades of such instruments that occurred during the 2007-2009 period, taking many such holdings from investment to speculative grades, significantly affected the regulatory capital of various financial institutions holding the downgraded instruments. An institution affected then faced a stark decision: either keep the downgraded instruments and find additional capital elsewhere or sell the downgraded instruments to reduce the required regulatory capital. At the same time, the downgraded instruments likely experienced severe price declines. A crucial input in the institution's decision is the accounting treatment used for the downgraded instruments (as well as the accounting treatment for other assets in its portfolio).

If the downgraded asset is held at market value, the price decline would be automatically reflected in the balance sheet, and the loss will flow to the income statement, impairing the institution's capital. From a purely accounting point of view, the institution will be indifferent between keeping the asset on the balance sheet and selling it. However, considering the regulatory capital dimension, selling the downgraded asset has an advantage as swapping a risky asset for cash reduces the required regulatory capital. The disadvantage of selling is that trades will take place in a market already characterized by severe price declines and illiquidity. 
The situation is different if the asset is held under HCA. In line with Allen and Carletti (2008), the decline in value will not be recognized in the balance sheet, but crucially, the institution still has to act because its regulatory capital would have increased as a result of the downgrade. Holding the asset has the advantage of limiting the unfavorable price impact, but additional capital needs to be raised. It is precisely in this situation that the incentive for gains trading arises. The institution may sell other existing assets that have not been downgraded to shore up its capital position. Importantly, the institution faces an altered incentive to do so by selectively selling those assets that are held under HCA and have the largest unrealized gains. By selling such assets, these unrealized gains can be recognized and flow to its capital.

The question then becomes whether such selective selling engenders significant price pressure in the selected assets with high unrealized gains. If so, one can conclude that HCA precisely because of the interaction between accounting and capital regulations - does not completely avoid illiquidity spillovers.

We investigate this gains trading mechanism during times of market stress by examining the behavior of 1,882 insurance companies following severe downgrades within the ABS market. Most importantly, we exploit the different accounting treatments used in determining the required capital for holding speculative-grade assets, under the National Association of Insurance Commissioners (NAIC)'s model law, for life and for property and casualty (P\&C) insurance companies. In the case of an ABS downgraded from investment to non-investment grade, $\mathrm{P} \& \mathrm{C}$ insurers have to immediately recognize the value of the ABS as the lower between the amortized value (based on HCA) and the market price (or model price, in case no market price is available). On the other hand, life insurers can continue to hold the downgraded ABS under HCA except in the extreme case when it is classified as 'in or near default' (Class 6). ${ }^{4}$ Given these distinctions in accounting treatment and the NAIC's security-level data, the insurance industry presents an interesting laboratory in which to explore the interplay between accounting and regulatory capital requirements for financial institutions.

We construct a dataset of 34,957 downgrades of non-agency ABS to speculative-grade by S\&P over the period 2005-2010 using S\&P’s Ratings IQuery. We combine information on these securities with firm-level observations, provided by the NAIC, on insurance companies' holdings

\footnotetext{
${ }^{4}$ To put the definitions of the asset classes in perspective, a "Class 5 ” security is one that corresponds to a CCC/Caa credit rating; even in such cases life insurers can continue to hold the asset at HCA while P\&C insurers have to recognize the market price if the price falls below the amortized value.
} 
of and transactions in individual ABS and corporate bonds. Further, for each ABS and corporate bond position, insurance companies provide, under statutory accounting principles prescribed by insurance regulatory authorities, both fair and book values to the NAIC. We obtain data on the financial position and strength of each insurance company from the Street.com.

As of 2007, life and P\&C insurance companies held roughly the same amount of nonagency $\mathrm{ABS}$ as a percentage of their total bond portfolio (around 5-7\%). During the financial crisis, the downgrades of some of these ABS instruments were severe, with the majority of downgraded securities falling to speculative grade. ${ }^{5}$ We find confirmation that the different accounting treatment between life and $\mathrm{P} \& \mathrm{C}$ insurers is triggered when such downgrades occur. For example, from 2004 to 2006, both life and P\&C insurance companies hold around 5\% of their non-agency ABS positions at market values. In 2008, almost 20\% (5\%) of the holdings of P\&C (life) are held at market values. Given that the exposure of both types of insurers to downgraded ABS is very similar, this evidence provides confirmation of the different accounting regulations across the two groups. Further, the statutory capital of life companies, due to HCA, is much less affected by the downgrades than the capital of P\&C firms (-6\% vs. -13\% from 2007 to 2008). For both groups, however, the regulatory capital requirement increased. The question is then how the different accounting treatments influence the incentives of life and P\&C firms to respond to this increase in their required regulatory capital.

Several key empirical results deserve attention. First, during the crisis, we find clear evidence that life firms (the financial institutions generally booking downgraded securities under HCA) largely keep the downgraded ABS in their balance sheet, whereas $\mathrm{P} \& \mathrm{C}$ firms (the institutions generally marking downgraded securities at fair values) disproportionately sell their downgraded ABS holdings (about 45\% more likely than life firms). While the selling of the downgraded ABS may take place at fire-sales prices, P\&C insurers, having already booked the loss, would be indifferent between holding the asset at the lower value and selling it. Selling the asset has an important advantage from the regulatory capital point of view, as a risky asset will be exchanged for cash thus reducing the capital requirement.

Second, we find that life insurers disproportionately sell the otherwise unrelated corporate bonds that have, on balance, the highest unrealized gains. Because most corporate bonds are also

\footnotetext{
${ }^{5}$ For example, out of the 1,238 ABS held by insurance companies that were downgraded to BB status, 946 were previously rated in the top three credit rating classes, with 451 coming straight from the highest AAA rating class.
} 
held at historical cost, it is only by the sale transaction that these unrealized gains can be recognized. Following this course of action, life insurers achieved two important objectives: (1) reduce their regulatory capital (exchanging a risky asset for cash) and (2) realize the gain that arises from the HCA treatment. Most importantly, we find that this trading behavior is disproportionately conducted by life insurers that have (a) large exposures to downgraded ABS booked at HCA, and (b) low risk-based capital ratios. Among these insurers, the probability of selling corporate bonds with the highest unrealized gains increases by more than 50\% over the normal selling probabilities. ${ }^{6}$ These results are obtained after controlling for standard insurance company and bond characteristics. ${ }^{7}$

Finally, we consider whether the gains trading engaged in by life insurers leads to price pressure in the corporate bond market. If a large number of insurance companies attempt to sell corporate bonds with the largest unrealized gains in a market that is notoriously illiquid, then we should expect significant price pressures. We find that the price at which insurers with the highest pressure sell their bonds is significantly lower than the median price of the same bond during the week of this trade. Further, we also find that the corporate bonds disproportionately targeted by insurers facing the highest propensity to gains trade statistically and economically underperform otherwise similar bonds. The quarterly return is $0.7-1.3 \%$ lower as we move from the $25^{\text {th }}$ to $75^{\text {th }}$ percentiles of aggregated gains-trading propensity. No such price impacts are experienced for the corporate bonds selling by P\&C insurers.

Overall, these results show that the interactions between accounting treatment, especially HCA, with capital regulations can create unintended consequences where spillover effects and fire sales are not entirely avoided. HCA, through the incentive it creates for gains trading, can still engender price distortions during market stress for assets that are completely unrelated to the original downgraded securities. Thus, using the terminology in Plantin et al. (2008) "in such an environment, prices drive measurement, but measurements have an impact on pricing.” The results

\footnotetext{
${ }^{6}$ The marginal selling probability is calculated by comparing the selling probability between the corporate bonds at the $75^{\text {th }}$ percentile of unrealized gains and the bonds at the $25^{\text {th }}$ percentile.

${ }^{7}$ While the majority of the insurers in our sample are private firms, some are publicly listed. Given that the majority of insurance company positions are listed as "available for sale" and hence marked to market under GAAP (as opposed to the statutory accounting principles highlighted here), we explore the robustness of our main results for the two groups separately. The results are broadly similar, suggesting that the additional disclosure associated with public firms does not significantly alter the incentives generated by HCA versus fair value accounting as they interact with regulation.
} 
for life insurers are of particular importance to banking institutions since life insurers, in contrast to P\&C, have asset and liability structures that resemble those of banks.

Our paper is related to several strands of the literature. We contribute to the growing literature exploring the trading decisions made by institutional investors when faced with a financial shock (for example, Anand et al. (2010), Boyson et al. (2011), Manconi et al. (2011), Hau and Lai (2011), among others). To the best of our knowledge, we are the first to empirically demonstrate the importance of the interaction between accounting and capital regulations on the decisions made by institutional investors and the spillover effects that may occur. One unintended consequence of such an interaction, which we focus on in this paper, is the incentive for gains trading; Beatty, Chamberlain, and Magliolo (1995), Hirst and Hopkins (1998), Hirst et al. (2004), Kashyap and Stein (2000), Lee et al. (2006), among others, also explore the gains trading (what these articles refer to as the 'cherry picking') phenomenon. In contrast to these earlier efforts, we show that gains trading behavior takes place during periods of market stress and has significant price impacts. Furthermore, we are the first to document such trading behavior at the securitylevel, rather than inferring trading behavior from aggregated data at the institution-level. ${ }^{8}$

Finally, and most importantly, our results contribute to the debate on the choice of accounting system, historical cost vs. marking to market, used in regulating financial institutions. ${ }^{9}$ The literature (mostly theoretical) suggests that during a financial crisis, marking to market may cause distressed selling and financial instability (Allen and Carletti (2008), Plantin et al. (2008), and Wallison (2008)). ${ }^{10}$ We provide new empirical evidence that suggests that the contentious debate about accounting choices for financial institutions in general cannot focus exclusively on accounting treatments but rather must acknowledge important interactions with the regulatory framework in which they are being employed. Specifically, our evidence supports Laux and Leuz (2009, 2010)'s conjecture that historical cost accounting is not a panacea. Historical cost accounting creates an altered-incentive environment in which financial institutions sell assets to realize gains, essentially transmitting shocks across potentially unrelated markets.

\footnotetext{
${ }^{8}$ Our results also imply that reported income that includes realized gains and losses may not be reflective of insurers' financial health and valuation, consistent with the findings of Nissim (2011).

${ }^{9}$ See Goh et al. (2009) for a general analysis of the determinants of accounting choice and the effects of fair value disclosure on firms' information environment. See also Eccher, Ramesh, and Thiagarajan (1996), Penman (2007), Petroni and Wahlen (1995), and Wyatt (1991).

${ }^{10}$ See Veron (2008), and Bleck and Liu (2007) for an opposing view.
} 
The remainder of the paper is organized as follows. Section 2 discusses the sample construction and describes the summary statistics of the data. Section 3 presents our main empirical analysis and discusses the results. Section 4 concludes.

\section{The Data}

We are interested in providing evidence concerning the contentious debate over historical cost versus fair value accounting for financial institutions. In particular, how do these different accounting rules, coupled with the overall regulation, affect the institutions' risk taking activities? The insurance industry provides a natural laboratory in which to empirically examine this question. First, there exist significant differences in regulatory accounting rules: life insurers have greater flexibility to hold downgraded assets at amortized historical cost than property and casualty (P\&C) insurers. Second, within an insurer's investment portfolio, detailed data are available on transactions, positions, and, most importantly, the accounting treatment for each security.

\subsection{Sample Construction}

We combine three sets of data in our analysis: information on insurance companies, ABS securities and their rating changes, and corporate bonds and their trade prices. We discuss in detail how we assemble the three sets of data below. Our sample period is from 2004 to 2010. This period covers the financial crisis of 2007-2009 and also a non-crisis period that we shall use for comparison. Specifically, we define our crisis period as 2007 Q3 - 2009 Q4, as virtually all significant downgrades of ABS happen during this period.

Our primary data on insurance companies' transactions and year-end positions are from the National Association of Insurance Commissioners (NAIC). ${ }^{11}$ The NAIC data provide year-end holdings of invested securities for each insurance company and detailed transaction information on every trade. Both the position and transaction data provide the identities of the insurance firms and the relevant securities (e.g., 9-digit CUSIP). We merge the year-end position data with transaction data to infer quarter-end positions. Finally, the NAIC data provide detailed information about the book-adjusted carrying value and fair value of each position held by each insurance company at

\footnotetext{
${ }^{11}$ Further details of the NAIC data can be found in Ellul, Jotikasthira, and Lundblad (2011).
} 
year-end. We employ this information to infer whether an insurance company holds its ABS and corporate bonds at historical cost or at fair value.

The financial information on each insurance firm is from the Street.com, which provides financial strength ratings. From this source, we obtain annual firm characteristics, such as size, 'capital and surplus', and the risk-based capital (RBC) ratio used for capital regulation. While our Street.com data end in 2007, we use the 2007 to infer subsequent values since these characteristics do not vary much over time. We eliminate small insurers with investment assets less than \$13 million (the bottom 1\%) and/or with an RBC ratio either below 2 or above 20 to avoid any bias from small or abnormal firms. ${ }^{12}$ We also delete all AIG's affiliated insurers and 32 others that provide financial insurance and guarantees for bonds, such as credit default swaps and municipal finance, as these firms were affected by the downgrade of ABS securities through a different channel. $^{13}$ Our final sample of insurance firms consists of 12,555 firm-years representing 2,249 firms, among which 577 are life insurers and 1,672 P\&C insurers.

Our data on ABS ratings are from S\&P's Ratings IQuery. We extract all the data in the structured credit subsector in Ratings IQuery, which comprehensively covers initial ratings and histories for all securitized issues rated by S\&P from 1991 to 2010. The database records issue and tranche identity (9-digit CUSIP), gross principle, class, maturity, collateral type, rating, and rating date. With this dataset, we identify 127,719 ABS securities in 13,430 issues. ${ }^{14}$ Among all the ABS securities rated by S\&P, 65\% are mortgage-backed securities, 20\% are collateralized debt obligations, and 15\% are asset-backed securities backed by consumer loans. We use the list of 9digit CUSIP of ABS in the rating dataset to identify holdings of ABS by insurers. Over our sample period, 24,452 unique CUSIPs in the portfolios of insurance firms are identified as ABS. The ratings and ratings dates are then used to generate the list of significant ratings downgrades.

\footnotetext{
12 Small insurance firms do not have many trading choices. Insurance firms with larger RBC ratios are considered better capitalized. Firms with RBC ratios below two are subject to supervisory intervention. Firms with RBC ratios above 20 are unusual and may behave differently from the average.

${ }^{13}$ We identify bond insurers from Ratings IQuery, which reports financial insurance providers in securitized issues. In addition to AIG, we also exclude Ambac Assurance Corp, MBIA Insurance Corp, Financial Guaranty Insurance Co., etc.

${ }^{14}$ According to SEC (2011), S\&P ratings are outstanding for a total of 117,900 ABS securities as of year-end 2010. Note that ABS securities, particularly mortgage-backed securities tend to have long maturities, suggesting that most of the securities in our sample may still exist by year-end 2010. In addition, the majority of the ABS securities were issued after 2000 when this market grew substantially. According the SEC report, S\&P rated the largest number of ABS among all rating agencies. The number of S\&P's ratings is greater than Moody’s 101,546 outstanding ratings.
} 
The data on corporate bond characteristics and trading are obtained from Mergent Fixed Income Securities Database (FISD) and TRACE. We merge the FISD data with the position and transaction data of insurance firms to identify the corporate bonds being held and transacted as well as the bond characteristics, such as issue size, age, maturity, rating downgrades, and bankruptcy. When we identify downgrades of corporate bonds, we use S\&P's ratings whenever they are available, to be consistent with our data source of ABS ratings. When S\&P's ratings are missing, we use the ratings from Moody’s (or Fitch if Moody’s ratings are not available). Data on bond market transaction prices and size are from TRACE, which covers over-the-counter corporate bond market transactions for both investment and speculative grade bonds since 2004. We use the 9-digit CUSIP to merge bonds in FISD and in TRACE.

\subsection{Insurance Firms and Their ABS Exposure}

Table 1 shows summary statistics on several key financial variables for our sample firms at the end of 2007. A detailed description of the variables can be found in Appendix A.

[Insert Table 1 here]

At the end of 2007, we have complete financial information for 1,344 P\&C companies and 432 life companies in the sample. Life firms are larger than P\&C firms. Invested assets are $\$ 4.7$ billion, on average, (median of \$393 million) for life firms and \$829 million, on average, (median of \$119 million) for P\&C firms. The average 'capital and surplus' is also larger for life firms at \$476 million (median of \$66 million), compared to \$384 million (median of \$53 million) for P\&C firms. In addition, life firms, similar to banks, operate at much higher leverage than P\&C firms. Return on equity is at similar levels for the two types of firms.

The capital positions of life and P\&C firms are similar. We use the NAIC risk-based capital ratio (RBC ratio) to measure capitalization. The $\mathrm{RBC}$ ratio is the ratio of total adjusted capital to NAIC risk-based capital (RBC), which is the minimum capital under current regulation that an insurance company must maintain given the inherent risks in its operations. ${ }^{15}$ It is calculated based on the NAIC’s formula which reflects a risk assessment of different asset classes and businesses.

\footnotetext{
15 This is similar in idea to a variety of capital ratios (e.g. tier 1 capital/risk-weighted assets) used in bank regulations.
} 
Risky assets are weighted more heavily in computing RBC, and higher RBC ratios reflect better capitalization. Insurance companies with RBC ratios below 2 are considered under-capitalized and subject to supervisory interventions. The average life and P\&C firms in our sample have RBC ratios of 9.1 and 8.3, respectively. We use the RBC ratio to capture the regulatory constrains that insurers may face when their fixed income holdings are downgraded, as downgrades can lead to higher weights assigned on the same assets and hence a lower RBC ratio.

Insurance companies heavily invest in investment-grade bonds, representing 57-60\% of their portfolios, on average. The Street.com creates a series of standardized indices to measure insurers' liquidity, profitability, and other aspects of their financial conditions. Life and P\&C firms are, on average, not systematically different in terms of the Street.com's assessment of profitability and liquidity. Overall, as insurers heavily invest in bonds, their trading behavior in this asset class is representative of their portfolio choice and thus interesting to analyze.

To see the exposure of the insurance firms to ABS, we report their holdings of ABS over the period 2004-2010 in Table 2.

[Insert Table 2 here]

Life firms have greater exposures to ABS when compared to P\&C firms. Based on the left two columns, about 80\% (60\%) of life (P\&C) firms hold ABS. These percentages decline for P\&C firms over the crisis period. In the other columns, we report the number and total values of ABS in each year across the firms that hold any ABS. Three features of the data are notable. First, insurance firms' portfolio exposures to ABS were quite large during the crisis. For example, life firms held, on average, 75-79 ABS during 2007-2009, and these securities accounted for about 7$8 \%$ of the par value of their total fixed income holdings, including government, corporate, municipal and all other types of bonds, in addition to securitized instruments. P\&C firms held fewer ABS, compared to life firms, but the average exposure was still about 5\% in 2007 and 2008.

Second, we note that insurance firms built up their holdings of ABS before the crisis and reduced the exposure afterwards. For life firms, the ABS holdings accounted for 4.7\% (median $3.5 \%$ ) of par value of all bond positions in 2004, increased to 7.7\% (median 6.2\%) in 2007, and dropped to $5.7 \%$ (median $4.6 \%$ ) by the end of 2010. P\&C firms reduce their exposure earlier and more substantially than life firms. Their relative holdings, measured with par value, were reduced 
from the maximum of 5.5\% (median 3.8\%) in 2007 to 3\% (median 1.6\%) by 2010. We also compute ABS exposure using fair instead of par value. The last four columns show that the fair value of insurance companies' holdings was substantially lower than par value after 2008, suggesting that the values of ABS holdings were more affected by the crisis than those of the other types of bonds.

Finally, we point out the substantial heterogeneity in ABS exposure across insurance companies. For example, in 2007, the median life firm held only 15 ABS and those in the top percentile held more than 156 such securities. Similarly, the median firm invested 6.2\% of the bond portfolio in ABS, and the top percentile held 16.3\% in ABS. The same heterogeneity was also present among P\&C firms. We will use this heterogeneity to economically identify "gains trading," as those more affected by ABS downgrades and the associated price decline have greater incentives to realize gains in other asset classes in order to improve capital positions.

\subsection{Downgrades of ABS Securities and Impact on Insurance Companies}

The securitization market expanded substantially before the crisis of 2007-2009. Total ABS issuance grew from \$1.5 trillion in 2004 to \$2.3 trillion in 2007, according to Asset-Backed Alert. A key development in this market was the collateralized debt obligation (CDO), which, by pooling and tranching, created securities that have much better credit ratings than the collateral assets backing the issues. The better ratings of the ABS attracted investors that face regulatory constraints mechanically tied to credit ratings, such as insurance firms. Following the onset of the financial crisis, ABS were severely downgraded by major rating agencies. In Ratings IQuery, we find 39,464 ABS downgrade actions by S\&P in 2008.

We are particularly interested in the downgrades from investment to speculative grades, because these downgrades would force firms to apply higher risk weights thereby triggering larger capital requirements. Figure 1 presents the total number of investment-to-speculative downgrades of ABS on a quarterly basis.

\section{[Insert Figure 1 here]}

The massive downgrades started in Q3 of 2007, with 952 downgrades from investment to speculative grades. In each of the following four quarters, we observe more than 3,500 such 
downgrades. In total from Q3 of 2007 to Q4 of 2009, S\&P downgraded 33,917 ABS from investment grade to speculative grade.

To gauge the degree to which insurance companies were affected by these downgrades, we count the number of investment to speculative downgrades of ABS that were held by insurance firms. These numbers are also shown in Figure 1 on the right scale. Only a small portion of the downgrades in the early stage of the crisis affected insurers: before the end of 2008, about 5-9\% of the downgrades in each quarter affected insurance firms. Insurance companies were, however, more significantly affected by the ABS downgrades in 2009, representing $15-18 \%$ of the total number of downgrades of ABS in each quarter of that year. Moreover, we note that the downgrades in the later stage of the crisis were more severe. For example, 332 downgrades in 2008Q4 were straight from AAA to speculative grade, compared to only 94 of such downgrades in all of the preceding quarters. In 2009, a total of 887 downgrades affecting insurance firms were from AAA to speculative grade.

[Insert Table 3 here]

Table 3 shows the rating transitions of downgrades, many of which were by several notches, of the ABS held by insurance companies. For example, 1,238 ABS were downgraded to a BB rating class (for the sake of brevity, we aggregate all ABS that were downgraded to $\mathrm{BB}+$, $\mathrm{BB}$ or $\mathrm{BB}$ - in one class); 451 of these securities were rated as AAA before the downgrade. The same applies to the 1,639 ABS downgraded to the B rating class; 714 of them were previously rated as AAA. These dramatic shifts, which likely came as a surprise to insurers, significantly impacted the insurers' regulatory capital. In fact, when a bond or bond-like instrument is downgraded from either “Class 1" or “Class 2" to “Class 3”, which is equivalent to a downgrade from an investment grade rating class to a BB class, the required regulatory capital increases significantly for both life and P\&C insurance companies.

\subsection{Accounting Treatment of Downgraded ABS Securities}

We now explain the rules surrounding the accounting treatment imposed on life and $\mathrm{P} \& \mathrm{C}$ insurance companies, when the ABS they held were downgraded. NAIC regulations define 6 different classes by credit ratings, and all fixed income securities held by insurers fall into one of 
these classes. A particular threshold of importance is between Class 2 and Class 3; the former refers to a security with a BBB rating while the latter refers to a security with a BB rating.

When a fixed income security is downgraded from investment to non-investment grades, $\mathrm{P} \& \mathrm{C}$ insurers have to immediately recognize the value of the bond as the lower between the amortized value (based on HCA) and market price (or model price, in case no reliable market price is available). Life insurers face no such requirement; they can continue to hold the downgraded bonds under HCA, except in the extreme case when the bonds are classified as 'in or near default' (Class 6). A Class 5 security is one that corresponds to a CCC/Caa credit rating; even in such cases, life insurers can continue holding the security at amortized value while $P \& C$ insurers have to recognize the market price if the price falls below the amortized value.

At this stage, it is important to draw a distinction between the accounting rules followed by insurance companies when producing their financial statements for investors (GAAP) and those in the Statutory Accounting Principles (SAP) used by regulators. The main difference of interest for this paper is the way unrealized gains and losses on available-for-sale (AFS) securities are treated under the two methods. This is important in our context because the securities that are most likely to be targeted for sale once an ABS is downgraded are mostly classified as AFS in insurance companies' balance sheets. ${ }^{16}$ GAAP states that AFS securities should be booked at MTM and any unrealized gains and losses will flow into the insurance company economic capital (but not to the income statement, so long as the securities are not sold). ${ }^{17}$ SAP adopts a very different approach to AFS securities held by insurance companies because, in general, any unrealized gains and losses are excluded from the SAP economic capital calculation. ${ }^{18}$ Specifically in the case of downgraded securities to non-investment grades, as explained above, SAP allows more accounting flexibility to life insurers: while P\&C insurers have to immediately recognize the value of the bond as the lower between the amortized value and market price, life insurers face no such requirement.

In the light of these regulations, the significant ABS downgrades documented in Section 2.3 should generate significant cross-sectional variability in the accounting treatment of downgraded ABS between P\&C and life companies. To explore this, we use year-end positions

\footnotetext{
16 This inference is based on the balance sheet information of publicly listed insurance companies.

${ }^{17}$ The accounting rules of interest are SFAS 115 and SFAS 130.

18 The treatment afforded to unrealized gains and losses of AFS securities by SAP in the case of insurance companies is similar to that afforded by the Regulatory Accounting Principles in the case of banks.
} 
data, which contain the book value and the fair value (the market price or a model price for illiquid assets) reported for each position. We classify as "revalued" the positions for which the book and the fair values are equal. Others are classified as held at historical cost (i.e. treated under HCA). This identification of MTM vs. HCA may underestimate the frequency of MTM as no revaluation is required if the position's book value remains below its fair value (unlikely the case for recently downgraded ABS). However, we have no reason to believe that this underestimation affects one type of insurers more than the other; and, hence the difference in revaluation frequency across insurer type is most likely driven by different accounting treatments.

Figure 2 reports the percentages of ABS holdings (Panel A for investment-grade ABS and Panel $\mathrm{B}$ for speculative-grade ABS) revalued at year-end for both life and $\mathrm{P} \& \mathrm{C}$ over the period 2004-2010.

[Insert Figure 2 here]

The most striking feature is the significantly higher percentage of speculative-grade positions that were revalued by P\&C firms, far greater than those by life firms. In 2008, when a large number of ABS are downgraded and suffer severe price decline, $P \& C$ firms revalue $70 \%$ of their speculativegrade ABS, while life firms only revalue less than $20 \% .{ }^{19}$ Even for investment-grade ABS, P\&C firms appear to revalue their ABS positions more often than life firms during the crisis, possibly to impair some ABS whose changes in value are deemed permanent. Investment- and speculative grades combined, P\&C firms go from marking to market around 5\% of their ABS holdings in 2006 (similar to life firms) to marking to market almost $20 \%$ of their positions by 2009 . We attribute these differences in accounting treatment, starting from the end of 2007, to the different accounting regulations imposed on life vs. P\&C firms that become increasingly relevant when many of the ABS are downgraded to speculative grades.

An additional question that arises is whether different insurance firms agree on the accounting treatment used to book each downgraded ABS (which should be the case if the accounting treatment is determined by the regulation). We address this issue by investigating the revaluations of the ABS positions at the CUSIP level for both life and P\&C companies

\footnotetext{
${ }^{19}$ The difference is less striking but still significant in other years, as revaluation is not required if the book value is lower than the market value.
} 
(considering only those ABS that are held by at least two insurance companies within each group). We do not report these results for the sake of brevity; however, the picture that emerges corroborates the evidence in Figure 2. ${ }^{20}$

To better focus on the change in the accounting treatment, we investigate the differences across life and P\&C companies in their subsequent accounting treatment of the downgraded ABS. This analysis is shown in Table 4, for two types of downgrades (a) from investment to speculative grades, and (b) from AAA to speculative grade (this being the most severe type of downgrades).

\section{[Insert Table 4 here]}

There are striking differences between life and P\&C companies. Consider row (2), which include all downgrades from AAA to speculative grade over the period 2005-2010. We see that life insurers had a total of 1,860 positions in these securities that were held under HCA before the downgrade. Once the downgrade occurred, life insurers kept 79\% of those securities at amortized value and revalued only 9\% to market values. Compare this to the behavior of P\&C firms that held 851 downgraded ABS positions at amortized value before the downgrade. Once the downgrade occurred, P\&C firms kept only $45 \%$ of these securities under HCA, revalued $36 \%$ to market values (three times as much as life firms did), and sold 20\%.

One drawback of the NAIC balance sheet data for this particular type of analysis is that the positions are available only at the year-end. It is plausible that revaluations occur at different times within the year. Since we only observe the difference between the book value and fair value at year-end, this may lead to some bias against finding revaluations if market prices subsequently drift (recall that revaluation is required only when the market value falls below the original book value). This may have happened, for example, during 2009 when many of the extreme downgrades took place relatively early in the year. To address this issue, we consider a subset of downgrades that occurred in the fourth quarter, as these are temporally closer to the year-end

\footnotetext{
${ }^{20}$ For example, $91 \%$ of all ABS held by at least two life firms are booked at historical cost in 2006, and 92\% in 2009. The picture is very different for P\&C: in 2006, $88 \%$ of all ABS were held at historical cost, but that figure decreases to $65 \%$ in 2008, $72 \%$ in 2009 and $68 \%$ in 2010 . Around 4\% of ABS were held at market value by all P\&C firms in 2006, but this figure rose to $21 \%$ in 2008 . Finally, we find that there is some disagreement on the same ABS across insurance companies in both groups, but such disagreement is much lower in the life group than P\&C group. It is possible that such disagreement arises because of the limited discretion in the hands of each insurance company when determining the fair value of each ABS and whether the change in value is temporary or permanent nature.
} 
measurement we observe and the drift problem may be less important. As expected, the results are more striking. Life insurers had a total of 514 positions in ABS securities that were downgraded from AAA to speculative grade and were held at amortized value before the downgrade. Once the downgrade occurred, life insurers kept 79\% of these securities under HCA and revalued 10\% to market values. In contrast, $\mathrm{P} \& \mathrm{C}$ kept only $16 \%$ of the similarly downgraded securities at amortized value, revalued 63\% to market values (six times as much as life), and sold 11\%.

Taken together, we conclude that the differences in the regulation governing the accounting treatment between life and $\mathrm{P} \& \mathrm{C}$ firms draw a clear wedge between the two types. We employ this distinction, and the resulting impact on the way downgraded assets are booked, to explore the incentive for gains trading created by the interplay between accounting rules and regulatory capital requirements for financial institutions.

\subsection{Unrealized Gains and Losses}

For each bond position, we calculate the unrealized gain as the difference between the position's book-adjusted carrying value and fair value as a percentage of carrying value. As discussed, insurance companies report both the carrying values and the fair values of all bond positions at year end to the NAIC. Table 5 reports the distribution of the percentage unrealized gains (and losses) separately for life and P\&C. Panel A is for ABS, and Panel B is for corporate bonds.

[Insert Table 5 here]

Table 5 Panel A shows that up to the end of 2007, the median unrealized gain for ABS is close to zero, but in 2008 the median unrealized gains for life firms turns into unrealized losses to the tune of -30\% with over nine tenths of all ABS positions having unrealized losses and over one tenth having the losses exceeding 75\%. These unrealized losses slightly improve in 2009 and 2010, but the overall distribution remains negatively skewed. P\&C firms suffer unrealized losses to a much lesser degree, with the median unrealized gain coming back to around zero in 2009 and 2010. This sharp difference between the two groups may be due to the fact that $P \& C$ firms are forced to revalue the ABS that are downgraded to speculative-grade, essentially truncating the left tail of the unrealized gain distribution. In addition, life firms are likely to avoid selling their ABS in 2008-2009, as doing so would have a significant negative effect on their income and capital. 
Panel B of Table 5 shows that the distribution of unrealized gains for corporate bonds also suffers a negative shift in 2008, but quickly returns to normal in 2009. Interestingly, over a quarter of corporate bond positions have unrealized gains in 2008, suggesting that there is more flexibility to potentially realize these gains by trading. In 2009, over half of the corporate bond positions have unrealized gains for life and over three quarters for P\&C firms. As a result, we will use corporate bonds as the main asset class for studying gains trading among insurance companies.

\section{Empirical Methodologies and Results}

\subsection{Difference in Accounting Treatment of ABS}

As seen earlier, $\mathrm{P} \& \mathrm{C}$ firms revalue a larger proportion of their ABS positions than do life firms during the crisis. To ensure that this finding is indeed due to regulatory differences, rather than the difference in, say, the credit quality of the ABS held by the two types of insurers, we estimate a logit model for the probability that an ABS position is revalued controlling for credit quality and other distinct characteristics of the ABS:

$$
\operatorname{Pr}\left(M_{i, j, t}=1\right)=l\left(\delta_{0}+\delta_{P} P_{j}+\delta_{X} X_{i, t}+\delta_{W} W_{t}\right)
$$

where $l(\cdot)$ denotes the logistic probability function, $M_{i, j, t}$ is an indicator variable that equals one if the insurance company $j$ (holding bond $i$ ) revalues bond $i$ at the end of year $t$ and zero otherwise, $P_{j}$ is an indicator variable that equals one if the insurance company $j$ is a $P \& C$ insurer and zero otherwise, $X_{i, t}$ is a vector of bond i's static characteristics (e.g. issue size) and time-varying characteristics (e.g. remaining maturity) at the end of year $t, W_{t}$ is a vector of time-specific variables, and $\delta$ 's are the corresponding vectors of coefficients to be estimated. It is important to highlight that in all specifications, we include ratings group $^{21}$ (in $X_{i, t}$ ) and U.S. state of incorporation fixed effects (in $P_{j}$ ), as well as either a crisis indicator or year fixed effects (in $W_{t}$ ).

We estimate the model for the crisis $(2007-2009)^{22}$ and non-crisis (2004-2006, 2010) periods, both separately as well as together. We are interested in how P\&C firms' incremental

\footnotetext{
${ }^{21}$ The ratings fixed effects are equivalent to the NAIC class 1, 2, 3, separately, and classes 4-6 put together.

${ }^{22}$ Note that the logit is estimated for revaluations that can only be observed at a year-end frequency.
} 
propensity to revalue their ABS positions differs across the crisis (where many ABS are severely downgraded) and non-crisis periods. Given our use of interaction terms in a number of specifications, it is difficult within a logit specification to interpret parameter estimates for the property and crisis indicators in isolation. We therefore estimate and report the marginal effect of being a P\&C firm on the probability of revaluation by making 2,000 repeated draws from the (multivariate normal) distribution of parameter estimates and calculating a simulated sample of probability difference between life and P\&C firms (a) in the crisis vs. non-crisis periods and (b) for downgraded ABS vs. others. We then use the simulated sample of marginal effects to construct $90 \%, 95 \%$, and $99 \%$ confidence intervals to determine statistical significance. ${ }^{23}$ The results are shown in Table 6.

\section{[Insert Table 6 here]}

In column (1) of Table 6, we report the simplest specification in which we examine the behavior of $\mathrm{P} \& \mathrm{C}$ relative to life insurers during the non-crisis period, including ratings group, U.S. state of incorporation, and year fixed effects. In column (2), we have the same specification for the crisis period. We find that while the $\mathrm{P} \& \mathrm{C}$ indicator carries a positive coefficient for both the crisis and the non-crisis periods, it is only statistically significant during the crisis period, with the marginal effect being much larger during the crisis period (1.9\% vs. $8.2 \%)$. Considering that the average probability of a revaluation of ABS held by all insurance companies during the crisis period is $3.6 \%$ (during non-crisis period it amounts to 5.2\%), it is very evident that P\&C insurers do revalue significantly more than life insurers.

We find similar results in columns (3) and (4) when we consider an alternative specification that includes ABS-level control variables (while still using all fixed effects as before). In columns (5) to (8), we consider the entire sample from 2004 to 2010 together and introduce (a) a crisis indicator and (b) an interaction effect between the P\&C indicator and the crisis indicator. In column (5), for example, we show that P\&C companies have a slightly higher propensity to revalue assets compared to life companies, and this difference increases

\footnotetext{
${ }^{23}$ This methodology is standard for a non-linear model with many indicator variables (see Bratsberg, Raaum, and Roed (2010), for example) and/or interaction terms (see Scheve and Slaughter (1999), for example). See Norton, Wang, and Ai (2004) for a detailed discussion of both the problem and the STATA program they write to address it; however, in most of our settings, we cannot use their program directly.
} 
dramatically during the financial crisis consistent with the time-separated results. The results hold strongly in all specifications, largely unaffected by any control variables we include.

In columns (3), (4), (7), and (8), we also investigate the propensity to revalue downgraded ABS, by adding a downgrade indicator that takes the value of 1 when the ABS rating falls from investment to speculative grades. Recall that by regulation, $\mathrm{P} \& \mathrm{C}$ companies are required to book speculative-grade ABS at the lower between amortized cost and market value while life companies are required to do so only when the ABS are near or in default. Thus, the difference in revaluation probability should come out most strongly among the downgraded ABS. Indeed, we find that the marginal effects of P\&C indicator on revaluation are multiple times higher for the downgraded ABS than for others, during both the crisis (12.5\%) and non-crisis (14.2\%) periods. This striking result, consistent with our finding in Table 4, suggests that the wave of ABS downgrades during 2007-2009 is ideal for investigating the implications of HCA vs. fair value accounting.

Overall, these results show clearly that the different regulatory accounting treatments imposed on $\mathrm{P} \& \mathrm{C}$ and life firms have a significant impact on their revaluation behavior. To be clear, the higher propensity of $\mathrm{P} \& \mathrm{C}$ to revalue should be understood more as an outcome of regulations on the accounting treatment rather than voluntary choice. If it is true that accounting is not simply a veil but rather constitutes an important influence on real decisions in markets characterized by frictions, then we should expect to see differences in trading behavior across insurance firms that have different revaluation propensities. Specifically, we expect P\&C firms to behave differently from life firms when faced with the stark decision of how to adjust their portfolios in response to a high number of ABS downgrades, given that the same trading decision may have different implications under the different accounting rules.

\subsection{Selling of Downgraded ABS}

In this section, we assess whether the P\&C firms' revaluation of downgraded ABS to market values (which we have shown truncates the distribution of unrealized losses) makes them more likely to directly sell the downgraded ABS relative to their life counterparts. We model the probability of selling the downgraded ABS within 3 months after the downgrade having occurred as a logistic function: 


$$
\operatorname{Pr}\left(S_{i, j, k}=1\right)=l\left(\kappa_{0}+\kappa_{P} P_{j}+\kappa_{V} V_{i, j, k}+\kappa_{X} X_{i, k}+\kappa_{W} W_{k}\right)
$$

where $l(\cdot)$ denotes the logistic probability function, $S_{i, j, k}$ is an indicator variable that equals one if the insurance company $j$ (holding downgraded bond $i$ ) sells the downgraded bond $i$ within 3 months after downgrade event $k$ and zero otherwise, $P_{j}$ is an indicator variable that equals one if the insurance company $j$ is a P\&C insurer and zero otherwise, $V_{i, j, k}$ is an indicator variable that equals one if the insurance company $j$ holds the downgraded bond $i$ at market value at the yearend before event $k$ and zero otherwise, $X_{i, k}$ is a vector of bond $i$ 's static characteristics and timevarying characteristics just before event $k, W_{k}$ is a vector of time-specific variables for each event $k$, and $\kappa^{\prime}$ s are the corresponding vectors of coefficients to be estimated. In all specifications, we include ratings group, U.S. state of domicile and year fixed effects.

We estimate the model separately for (a) all downgraded ABS, (b) only the ABS that were downgraded from investment to speculative grades, and (c) only the ABS that were downgraded from AAA to speculative grade. The marginal effects of the $\mathrm{P} \& \mathrm{C}$ and revaluation indicators are calculated as described in Section 3.1. The results are shown in Table 7.

\section{[Insert Table 7 here]}

From column (1), we find that $\mathrm{P} \& \mathrm{C}$ companies have a higher propensity to sell the downgraded ABS (rather than keeping these ABS on their book) relative to life. This result is confirmed using the specification that includes ABS-level control variables (remaining maturity and the $\log$ of the issue size) and a revaluation indicator variable that captures the insurance company's decision to revalue the downgraded ABS. The revaluation indicator variable is used to control for the likelihood that insurance companies are more likely to sell positions that have been re-booked at market price because once they do so, they should be largely indifferent between keeping the asset on their balance sheet or selling it. In fact, the marginal effect of the revaluation indicator is positive and statistically significant in all specifications, showing that revalued positions are indeed more likely to be sold. It should be noted that these trading dynamics cannot be explained by any differences in regulations across different U.S. states since 
we include state of incorporation fixed effects. Further, these effects are not driven by ABS-level characteristics, such as liquidity, since we include ABS-level controls. ${ }^{24}$

The main result that $\mathrm{P} \& \mathrm{C}$ firms are more likely to sell downgraded ABS than life firms is confirmed for the more severe downgrades (a) from investment to speculative grades (columns (3) and (4)) and (b) from AAA to speculative grade (columns (5) and (6)). We want to highlight that for the last set (most severe downgrades), the effects of the P\&C indicator are about twice as large as those for the other types of downgrades. For these AAA-to-speculative-grade downgrades, and controlling for the revaluation effects, we find that the selling probability of P\&C firms exceeds the selling probability of life firms by 5.8\%. Considering that the average selling probability is $7.3 \%$ for these downgraded ABS, we can say that, $\mathrm{P} \& \mathrm{C}$ firms have an 80 percentage points higher propensity to sell than life firms. The same selling behavior is observed when we consider less severe downgrades from investment to speculative (45 percentage points) and all downgrades (53 percentage points).

These results, obtained at the individual ABS-level, are a confirmation of the broad industry trend shown in Table 2. Recall that the average holdings of ABS of life insurers was $6.58 \%$ in 2006 and was reduced to 5.15\% in 2009, while the average holdings of ABS of P\&C went from $5.08 \%$ to $2.75 \%$ over the same period.

In sum, the results from Table 7 exhibit a sharp contrast between P\&C and life companies: P\&C firms disproportionately sell their downgraded ABS holdings. This may very well be a consequence of the regulatory accounting treatment we document in Section 3.1. Since P\&C companies are forced to book the losses that result from severe downgrades, they would be indifferent between holding the asset at the lower value and selling it. More importantly, these trading dynamics may be the result of the interactions between those accounting rules and the regulatory capital requirements. For P\&C insurers, selling the speculative-grade asset has an important advantage from the regulatory point of view, as they are exchanging a very risky asset for cash (or even a less risky asset) thereby reducing their capital requirements.

\subsection{Propensity to Gains Trade}

In this section, we assess insurance companies' propensity to gains trade, defined as selectively selling the positions in the book that have high unrealized gains, when they hold these positions at

\footnotetext{
${ }^{24}$ In fact, the marginal effects of issue size show that large-issue ABS are more likely to be sold, possibly due to their superior liquidity.
} 
amortized historical costs. So far we have established that P\&C insurers are more likely to revalue the downgraded ABS to market prices and have a higher propensity to sell them relative to life insurers. Given that both $\mathrm{P} \& \mathrm{C}$ and life have roughly similar exposures to downgraded ABS securities, and thus a similar impact on their regulatory capital, this begs the question as to the actions taken by life insurers in response to this hit on their regulatory capital.

In continuing to hold their downgraded ABS positions, life companies may have the advantage of limiting an unfavorable price impact and avoiding the realization of losses, but additional capital may still be required. It is precisely here that gains trading becomes important. As a life firm attempts to sell its existing assets that have not been downgraded to shore up its capital, it has an incentive to do so by selectively selling those assets that have the largest unrealized gains. Only by selling these assets can these large unrealized gains be recognized and be applied to its capital.

Life companies engaging in gains trading have different asset classes from which to choose. It would be natural to consider government bonds which feature heavily in insurance companies' portfolio. However, selling government bonds does little to assist from a regulatory capital point of view because they are free from capital requirement. Insurance companies also hold equities, but we do not consider these positions since equities are held at market value. The other natural positions to consider are (mostly investment-grade) corporate bonds ${ }^{25}$, a significant number of which are carried at unrealized gains, as shown in Table 5. Another advantage of selling corporate bonds is that the insurance company will exchange a risky asset for cash, thereby reducing the required regulatory capital.

We model the probability of selling each corporate bond position as a logistic function:

$$
\operatorname{Pr}\left(S_{i, j, q}=1\right)=l\left(\gamma_{0}+\gamma_{Z} Z_{i, j, q}+\gamma_{X} X_{i, q}+\gamma_{Y} Y_{j, q}+\gamma_{W} W_{q}\right)
$$

where $l(\cdot)$ denotes the logistic probability function, $S_{i, j, q}$ is an indicator variable that equals one if the insurance company $j$ (holding bond $i$ ) sells bond $i$ in calendar quarter $q$ and zero otherwise, $Z_{i, j, q}$ is the percentile (ranging from 0 to 1 ) of unrealized gain of corporate bond $i$ in the portfolio

\footnotetext{
${ }^{25}$ On balance, there are various reasons to believe that corporate bonds will be preferred to equity for gains trading. First, insurance companies are significant investors in corporate bonds. Schultz (2001) and Ellul et al. (2011) estimate that insurance companies collectively hold between one-third and forty percent of investment-grade corporate bonds. At a weight of around 8\%, equities represent a much smaller segment of insurance companies' portfolios. Finally, and most importantly, equities are held at market value, and thus gains trading is not possible.
} 
of insurance company $j$ at the year-end prior to quarter $q, X_{i, q}$ is a vector of bond $i$ 's static characteristics and time-varying characteristics at the beginning of quarter $q, Y_{j, q}$ is a vector of financial and risk characteristics of insurance company $j$ at the year-end prior to quarter $q, W_{q}$ is a vector of time-specific variables for quarter $q$, and $\gamma^{\prime}$ s are the corresponding vectors of coefficients to be estimated. The results are shown in Table 8.

\section{[Insert Table 8 here]}

We start by comparing the results during the crisis period for life insurers, shown in columns (1) and (2), with those for P\&C insurers, shown in columns (7) and (8). Considering the first row in Panel A, assuming that the insurance firms do not have high ABS exposure and low $R B C$ ratio (hence all interaction terms are zero), we find that life companies have a positive and statistically significant propensity to sell corporate bonds at higher levels of unrealized gains. Interestingly, the same coefficient is negative for P\&C firms. When we compare the propensity of the life and P\&C insurers during the non-crisis periods (results shown in columns (3) and (4) for life and columns (9) and (10) for P\&C), we also find a significant difference between the two groups. In normal times, life insurers are actually less likely to sell bonds with high unrealized gains (possibly to avoid tax) ${ }^{26}$ while P\&C firms' trading is insensitive to unrealized gains. Overall, life insurers appear to engage in gains trading only during the crisis period, while they tend to sell their corporate bonds with the lowest unrealized gains during the non-crisis period. No such behavior is detected for P\&C companies.

We next investigate the impact of each insurance company's exposure to ABS assets held at amortized historical cost on the propensity to engage in gains trading. We have argued that this is precisely a factor that may lead insurance companies to gains trade. We find that while life insurers with high ABS exposure (held at book values) sell more frequently corporate bonds (possibly just turning over their portfolios more often) in general (second row), they do not appear more likely to gains trade during the crisis (third row of columns (1) and (2)). These life firms tend to sell corporate bonds with the lowest unrealized gains during the non-crisis period (third row of columns (3) and (4)). These life firms thus change their behavior from the non-crisis

\footnotetext{
${ }^{26}$ See Jin (2006).
} 
period (selling of corporate bonds with lowest unrealized gains) to the crisis period. Interestingly, the results for $\mathrm{P} \& \mathrm{C}$ also confirm that gains trading is associated with historical cost accounting. Recall that the variable "High ABS exposure dummy" refers to ABS held at amortized historical cost. Thus, even in P\&C companies, high exposure to ABS held under HCA should still induce gains trading. For both life and P\&C companies, however, our unreported results show that the incremental effects of ABS exposure on gains trading are economic very small (less than $0.3 \%$ probability as we move from the 25th to 75th percentiles of unrealized gain).

The other important dimension to consider in the decision to gains trade is the regulatory capital pressure that each insurance company faces at times of severe downgrades. We explore this additional dimension by investigating the impact of the firm-level risk-based capital (RBC) ratio. Recall from Section 2 that the RBC ratio is the ratio of total adjusted capital to NAIC riskbased capital. It is important to note that the insurance literature views RBC ratios as indicative of financial health rather than categorical (e.g. above or below two is not a sole criterion for regulatory scrutiny) and the higher is the ratio the lower are the regulatory constraints.

To fully understand the dynamics of the interactions between accounting treatment and regulatory capital, we use three different variables: (a) an indicator variable to capture insurance companies with low $\mathrm{RBC}$, defined as the RBC of insurers in the bottom quartile of the $\mathrm{RBC}$ ratio distribution, (b) an interaction term between the low RBC ratio indicator and the unrealized gains percentile, and (c) a triple interaction term between the low RBC ratio indicator, the unrealized gains percentile and the high ABS exposure held at amortized historical cost indicator variable. We find evidence indicative of the impact of the interaction between accounting treatment and capital regulations. While life insurers with low RBC ratio and high ABS exposure are more likely to engage in gains trading during the crisis, we find no such behavior for $\mathrm{P} \& \mathrm{C}$ companies.

So far, we have investigated the trading behavior of insurance firms during crisis and noncrisis periods, separately. We also estimate the propensity to engage in gains trading for the entire sample for life insurers, in columns (5) and (6), and for P\&C insurers, in columns (11) and (12). In such specifications we introduce a crisis indicator variable and interact this indicator with other variables of interest. This pooled specification broadly confirms the evidence in the timeseparate estimations. First, life insurers appear to engage in gains trading during the crisis period, whereas the coefficient estimate for $\mathrm{P} \& \mathrm{C}$ is found to be negative. Second, the quadruple interaction term (in row 14) where we interact the crisis indicator with the low RBC ratio 
indicator, the unrealized gains percentile, and the high ABS exposure held at historical cost indicator confirms that life companies facing regulatory constraints and holding significant ABS positions under HCA disproportionately sell corporate bonds with high unrealized gains during the crisis. No such action is observed for P\&C companies.

Given the non-linear nature of the logistic function and our heavy use of interaction terms, a more accurate way to understand the sign, magnitude, and economic significance of these results, is to investigate the marginal effects (estimated via simulation). Panel B of Table 8 provides the estimates of the marginal effects using the models for the entire sample period (shown in columns (5) and (6) for life and columns (11) and (12) for P\&C). We estimate the marginal effects on gains trading considering two cases for each group: (a) insurers with low exposure to ABS held at historical costs and high RBC ratios (denoted as "High ABS exposure dummy $=0$ and Low RBC ratio dummy =0” in Panel B), and (b) insurers with high exposure to ABS held at historical costs and low RBC ratios (denoted as "High ABS exposure dummy $=1$ and Low RBC ratio dummy = 1" in Panel B). Note that the average selling probability of a corporate bond held by life companies over the entire period is $4.2 \%$. Consider two similar corporate bonds held by a life firm with high ABS exposure and low RBC ratio, one with unrealized gain at the 25th percentile of the firm's portfolio and the other with unrealized gain at the 75th percentile. Using the estimates from model (5), the second bond is significantly less likely than the first bond to be sold during the non-crisis period (by 1.0\%) but is significantly more likely during the crisis (by 1.3\%). The difference is equivalent to an increase of the probability of selling by $2.3 \%$, almost 55 percentage points of the average selling probability for the entire period. Similar results are obtained when we estimate the marginal effects using the model shown in columns (6) in Panel A. In sharp contrast, all the marginal effects for corporate bonds held by P\&C companies are statistically and economically insignificant, confirming the indicative results found in Panel A. While we find that life companies with low ABS exposure and high RBC ratio also engage in gains trading during the crisis, the effect is much smaller than that found among the companies with high ABS exposure and low RBC ratio. This result is consistent with the important interplay between regulatory capital and accounting treatments.

It is also important to note that the probability of gains trading of life insurers is robust to the inclusion of a host of control variables that may be associated with selling for unrelated reasons. Panel C reports the marginal effects of control variables, where the effects are calculated 
by moving the value of continuous variable from the 25th to 75th percentiles or moving the value of dummy variables from 0 to 1 . The first notable variable is liquidity. The corporate bond literature has found that bid-ask spreads increase with bond age and decrease with bond issue size (see Edwards, Harris and Piwowar (2007)). ${ }^{27}$ In all specifications, we include the log of the corporate bond age and the log of the corporate bond size issue and thus liquidity considerations should not drive our results. However, it is also important to note that we find that insurance companies are more likely to sell younger bonds and bonds with larger issue size. One interpretation of these results is that insurers actively try to minimize any negative price impact by avoiding the sale of illiquid corporate bonds.

Other significant control variables include an indicator that measures whether the position is revalued at the previous year-end, an indicator that measures whether the bond is downgraded to the speculative class during the quarter, an indicator that captures whether the bond issuer filed for bankruptcy during the quarter, and depending on specifications, the proportion of risky assets in an insurer's portfolio (capturing the insurer's risk appetite or its capacity to bear risk) as well as the insurer's book leverage. Bonds that are revalued at the previous year-end are about $0.8-4 \%$ more likely to be sold, consistent with the result for ABS. Bonds that are downgraded to the speculative grade or bonds of the issuers that recently go into bankruptcy are 5-24\% more likely to be sold. This may be due to the differential degrees of negative information across rating classes or the regulation that imposes much higher capital charge for holding speculative-grade bonds, as discussed by consistent with the findings of Ellul et al. (2011). Finally, we find only weak evidence that insurers with higher leverage and insurers with higher risk appetite or higher capacity to bear risk (as proxied by their risky asset holdings) are more likely to sell corporate bonds.

It is important to note that the above results are obtained after the inclusion of year-quarter dummies, U.S. state (of domicile) dummies and rating group dummies. Thus, our results cannot be driven by market-wide conditions that occur during the time of downgrades, other regulations faced by insurance companies, which differ across U.S. states, or ratings of the bonds.

Finally, we perform two additional robustness checks, not tabulated for brevity. First, we examine our results separately for public and private insurance firms. While the majority of the

\footnotetext{
${ }^{27}$ See also Hong and Warga (2000) and Schultz (2001). Driessen (2005) uses bond age to identify the liquidity component of credit spreads.
} 
insurers in our sample are private, some are publicly listed. Public firms have to disclose unrealized gains/losses (under accumulated other comprehensive income) in their annual reports, as the majority of bond positions are classified as “available for sale” and hence marked to market under GAAP (as opposed to the statutory accounting principles highlighted here). This disclosure may alter the incentives generated by HCA vs. MTM as they interact with regulation. However, we find broadly similar results for both private and public insurers, suggesting that our findings are general and not driven by the disclosure requirement. Second, we examine whether gains trading is driven by the difference in leverage between life and $\mathrm{P} \& \mathrm{C}$ firms, rather than the difference in regulatory accounting rules (life insurers have significantly higher leverage than P\&C insurers, as reported in Table 1). We repeat our analysis for the groups of life and P\&C firms with leverage between 0.58 (25th percentile of P\&C firms) and 0.96 (75th percentile of life firms). The results are similar to those reported above, suggesting the driving factors are separate from leverage. Together, these additional tests show that our results are robust and consistent with the hypothesis that different accounting rules, as they are used for capital regulation, can alter incentives and thus trading behavior of financial institutions.

\subsection{Price Impact of Gains Trade}

The final question we address is whether the selective selling in Section 3.3 creates enough pressure in the targeted bonds to generate price distortions. In the case that such price pressures do occur, one can conclude that HCA - precisely because of its interactions with capital regulation - does not avoid spillovers and fire sales, as claimed by the existing theoretical literature.

We evaluate the price impact in two ways. First, for each sale transaction, we compare the sale price with the market median obtained from TRACE. Like any other investors, insurance companies pay transaction costs when they sell a bond to a dealer (as they demand liquidity); their sale price is, on average, lower than the market value. Since only bond positions with sufficiently large unrealized gain can be used for gains trading, insurers may have to concede even more to sell this limited number of positions during the crisis. Second, at the bond level, we compare the quarterly return across bonds that are subject to different degrees of gains trading.

Schultz (2001) and Ellul et al. (2011) estimate that insurance companies collectively hold between one-third and forty percent of investment-grade corporate bonds. If insurance companies 
demand liquidity when they sell bonds to realize gain, elevated gains trading should put more pressure on the overall market price. We thus expect the bonds most targeted for gains trading to underperform otherwise similar bonds.

At the transaction level, we measure the price impact of each transaction as the percentage discount of the sale price relative to the median market price during the week, $\ln \left(P_{i, j, w} / \bar{P}_{i, w}\right)$, where $P_{i, j, w}$ is the transaction price of bond $i$ sold by insurance company $j$ in week $w$ and $\bar{P}_{i, w}$ is the median market price of bond $i$ in week $w$. To ensure the reliability of our median price, we only use the bond-weeks in which there are at least 3 transactions in the same bond. We model the price impact as

$$
\ln \left(P_{i, j, w} / \bar{P}_{i, w}\right)=\beta_{0}+\beta_{Z} Z_{i, j, w}+\beta_{X} X_{i, w}+\beta_{Y} Y_{j, w}+\beta_{W} W_{w}+\varepsilon_{i, j, w}
$$

where $Z_{i, j, w}$ is a vector of characteristics of a sale transaction of bond $i$ by insurance company $j$ in week $w, X_{i, w}$ is a vector of bond i's static characteristics and time-varying characteristics at the beginning of week $w, Y_{j, w}$ is a vector of financial and risk characteristics of insurance company $j$ at the year-end prior to week $w$ (including the dummies for the company's domicile state), $W_{w}$ is a vector of time-specific variables for week $w$, and $\beta^{\prime}$ s are the corresponding vectors of coefficients to be estimated. Wherever the specification allows us, we include ratings group, U.S. state of domicile, and year fixed effects.

Our interested variable is the marginal effect of unrealized gain percentile (relative to mean) on the selling probability, which is part of the vector $Z_{i, j, w}$. We measure this marginal effect using the model similar to the models shown in columns (2) in Table 8, estimated crosssectionally for each calendar quarter. This marginal effect is specific to each bond position so that even the same bond may have different marginal effects depending on the insurance company holding the bond, the price at which the bond is acquired, and the period in which we measure the selling probability. We estimate the above model (4) by OLS, and cluster the standard errors by bond issuer. The results are shown in Table 9.

[Insert Table 9 here] 
Table 9 columns (1) and (4) show that for both life and P\&C insurers, the price impact of selling is significantly higher during the crisis (by about 30-50 basis points). Columns (2), (3), (5), and (6) analyze whether this increased price impact is related to gains trading. To do so, we include the interaction variable between the crisis indicator and the gains trading selling pressure. We find that the coefficient estimates are negative and statistically significant for life firms but are not significant for $\mathrm{P} \& \mathrm{C}$ firms. This result clearly shows that the gains trading, in which life insurers engage, is potentially expensive. As we move from the 25th to 75th percentiles of the gains-trading selling pressure for life companies during the crisis, the price impact increases by 915 basis points. This price impact is sizable, considering that the mean one-way transaction costs are about 15 basis points in normal markets (see Edwards et al. (2007)). It is important to stress that our estimate of price impact is obtained after controlling for various bond-level, insurancelevel, market-wide, and transaction-specific effects.

If a large number of insurance companies attempt to gains trade using the same corporate bonds in an illiquid market, then we should expect the bonds to suffer significant price pressures. To investigate whether this is the case, we move from the transaction level to the bond level. Using the transaction prices from TRACE, we calculate the quarterly return of a bond as the logged change in price from the last day of the previous quarter to the last day of the current quarter. This return measure is far from perfect. First, corporate bonds do not trade every day so the last day on which we observe trades for each bond may often be a few days before quarterend. We however find that for the bonds in our data that pass our screen, approximately $90 \%$ of the last trading days that we use fall in the last month of the quarter. Second, the holding period over which we measure the bond return may be greater than one or two quarters (if the bond is last traded a few quarters back). This problem affects less than $5 \%$ of the observations. We address these two problems, which result in irregular holding periods, by measuring the values of (some) control variables over the same period in which the bond return is measured. Finally, a bond may trade a few times in a day and the trade prices can be very different. ${ }^{28}$ Since corporate bond prices are more accurate for larger trades, we use the size-weighted average of all trade prices on the last day of a quarter.

Our model of quarterly bond return is as follows:

\footnotetext{
${ }^{28}$ See Bao, Pan, and Wang (2011), Feldhutter (2011), and Jotikasthira (2008), for example.
} 


$$
R_{i, q}=\beta_{0}+\beta_{X} X_{i, q}+\beta_{W} W_{q}+\xi_{i, q}
$$

Where $R_{i, q}$ is the return of bond $i$ in quarter $q, X_{i, q}$ is a vector of bond static and time-varying characteristics at the beginning of quarter $q, W_{q}$ is a vector of time-specific variables (including the Treasury and rating- and maturity-matched credit spread returns) for quarter $q$, and $\beta^{\prime}$ s are the corresponding vectors of coefficients to be estimated.

Our variable of interest is the selling pressure associated with unrealized gains, which we measure in two broad ways. First, we use the bond-level averaged marginal effects of unrealized gain on selling probability. The marginal effect for each bond position is calculated as the predicted value (relative to mean) obtained from the logit model similar to column (2) in Table 8, estimated separately for each calendar quarter. For each bond in each quarter, we then take (value-weighted or equally-weighted) averages of the marginal effects across the positions of all insurance companies in the particular bond. Second, we also consider the percentage unrealized gains, averaged across all positions in the bond. Although this measure does not reflect the fact that the same unrealized gains may have different effects on selling propensity for different insurance companies, it is not affected by possible misspecifications of our logit model. These selling pressures from gains trading enter the model as part of the vector $X_{i, q}$.

We distinguish the effect of gains trading from other effects of unrealized gains by interacting our measures of selling pressure with the crisis indicator. The selling pressure from gains trading should only operate during the crisis where insurers are hit by ABS downgrades and the huge unrealized losses of ABS positions in their portfolios. We only include the pressure from life firms, as we have shown in Table 8 that $\mathrm{P} \& \mathrm{C}$ firms do not appear to significantly gains trade.

We estimate the above model (5) by OLS, and cluster the standard errors by bond issuer. We include standard control variables for the fundamental movement in the bond price, using maturity-matched Treasury and rating- and maturity-matched credit spread returns. We use the interpolated constant maturity Treasury bond/note from the Fed to calculate the Treasury return. The spread return is the corporate bond index return minus the Treasury return, where we use the rating- and maturity-matched Bank of America-Merrill Lynch bond index as our primary source. 
Since the maturity group for the index is broad, we also adjust for the duration difference between the index and the bond of interest to ensure accuracy. Finally, we control for bond-specific characteristics, particularly bond age and issue size, which are key determinants of bond liquidity. Rating group and calendar quarter dummies are also included. The results are shown in Table 10.

\section{[Insert Table 10 here]}

We find clear evidence that the corporate bonds disproportionately targeted by life insurance companies for gains trading statistically and economically underperform otherwise similar bonds. The coefficient estimate of the interaction variable of interest (the crisis indicator interacted with gains-trading selling pressure) is always negative whether we use an equalweighted or a value-weighted methodology and whether we use marginal effects of unrealized gain on selling probability (columns (1) to (4)) or the percentage unrealized gains (columns (5) to (8)). Depending on specification, the quarterly return is $0.7-1.3 \%$ lower as we move from the $25^{\text {th }}$ to 75th percentiles of aggregated gains trading. Given that the inter-quartile range of quarterly bond abnormal return during the crisis is approximately $5 \%$, the magnitude of the selling pressure is economically significant. It is important to put this result in perspective: the selling pressure is generated by gains trading engaged in by life companies. This originates, in part, from their exposure to ABS held at amortized historical cost. We are documenting significant price declines in the corporate bond market, demonstrating spillover effects from downgraded ABS to otherwise unrelated corporate bonds through the interaction between the accounting treatment and regulatory capital requirements.

\section{Conclusions}

While the theoretical literature has argued that historical cost accounting may insulate financial institutions from the price distortions associated with market stress, we provide new empirical evidence supporting the view that historical cost accounting, along with regulatory capital requirements, induces an altered incentive to "gains trade" - that is, to selectively sell otherwise unrelated assets with high unrealized gains. Given (a) the distinction in regulatory accounting treatment across life and property and casualty insurance companies and (b) the availability of security-level data on all positions held, traded, and booked by insurers, the insurance industry 
presents an interesting laboratory to explore the interplay between accounting and regulatory capital requirements for financial institutions.

In contrast to property and casualty insurers, life insurers have a greater degree of regulatory flexibility to hold downgraded instruments at historical cost. When faced with severe downgrades among their holdings in asset-backed securities (ABS) during the financial crisis, life insurers, particularly those facing both regulatory capital constraints and high ABS exposures, largely continue to hold the downgraded securities at historical cost and instead selectively sell their unrelated corporate bond holdings with the highest unrealized gains. This behavior is largely absent among property and casualty insurers. As the observed gains trading by life insurers induces significant price declines for the corporate bonds that happen to exhibit high unrealized gains, we conclude that historical cost accounting does not completely avoid illiquidity spillovers.

\section{References}

Allen F. and E. Carletti, 2008, Mark-to-market accounting and cash-in-the-market pricing, Journal of Accounting and Economics 45, 358-378.

Anand, A., P. J. Irvine, A. Puckett, and K. Venkataraman, 2010, Market crashes and institutional trading, working paper, University of Georgia.

Bao, J., J. Pan, and J. Wang, 2011, The illiquidity of corporate bonds, Journal of Finance, forthcoming.

Beatty, A., S. L. Chamberlain, and J. Magliolo. 1995. Managing financial reports of commercial banks: The influence of taxes, regulatory capital earnings, Journal of Accounting Research 33, 231-261.

Bleck, A., and X. Liu, 2007, Market transparency and accounting regimes, Journal of Accounting Research 45, 229-256.

Boyson, N., J. Helwege, and J. Jindra, 2011, Crises, liquidity shocks, and fire sales at financial institutions, working paper, University of South Carolina.

Bratsberg, B., O. Raaum and K. Røed, 2010, When minority labor migrants meet the welfare state, Journal of Labor Economics 28, 633-676.

Carey, M., 1994, Snacking and smoothing: Gains trading of investment account securities by commercial banks, working paper, Board of Governors of the Federal Reserve System.

Driessen, J., 2005, Is default event risk priced in corporate bonds? Review of Financial Studies 18, 165-195. 
Duffie, D., 2010, Presidential address: Asset price dynamics with slow-moving capital, Journal of Finance 65, 1237-1267.

Eccher, E. A., K. Ramesh, and S. R. Thiagarajan, 1996, Fair value disclosures by bank holding companies, Journal of Accounting and Economics 22, 79-117.

Edwards, A., L. Harris, and M. Piwowar, 2007, Corporate bond market transaction costs and transparency, Journal of Finance 63, 1421-1451.

Ellul, A., C. Jotikasthira, and C. Lundblad, 2011, Regulatory pressure and fire sales in the corporate bond market, Journal of Financial Economics, 2011, 101, 596-620.

Feldhutter, P., 2011, The same bond at different prices: Identifying search frictions and selling pressures, Review of Financial Studies, forthcoming.

Goh, B.W., Ng, J., and Yong, K.O., 2009, Market pricing of banks' fair value assets reported under SFAS 157 during the 2008 economic crisis, working paper, Singapore Management University.

Heaton, J., D. Lucas, and R. McDonald, 2010, Is mark-to-market accounting destabilizing? Analysis and implications for policy, Journal of Monetary Economics 57, 64-75.

Hirst, D., and P. Hopkins, 1998, Comprehensive income reporting and analysts' valuation judgments, Journal of Accounting Research 36 (Supplement), 47-75.

Hirst, D., P. Hopkins, and J. Wahlen, 2004, Fair values, income measurement, and bank analysts' risk and valuation judgments, The Accounting Review 79, 453-472.

Hong, G., and A. Warga, 2000, An empirical study of bond market transactions, Financial Analysts Journal 56, 32-46.

Jin, L., 2006, Capital gains tax overhang and price pressure, Journal of Finance 61, 1399-1431.

Jotikasthira, C., 2008, Does search friction really matter? Evidence from the corporate bond market, Working paper, University of North Carolina at Chapel Hill.

Kashyap, A. K. and J. C. Stein, 2000, What do a million observations on banks say about the transmission of monetary policy? American Economic Review 90, 407-428.

Laux, C., and C. Leuz, 2009, The crisis of fair-value accounting: Making sense of the recent debate, Accounting, Organizations and Society 34, 826-834.

Laux, C., and C. Leuz, 2010, Did fair-value accounting contribute to the financial crisis? Journal of Economic Perspectives 24, 93-118.

Lee, Y-J, K.R. Petroni, and M. Shen (2006), Cherry picking, disclosure quality, and comprehensive income reporting choices: The case of property-liability insurers, Contemporary Accounting Research 23, 655-692. 
Manconi, A, M. Massa, and A. Yasuda, 2010, The behavior of intoxicated investors: The role of institutional investors in propagating the crisis of 2007-2008, Journal of Financial Economics, forthcoming.

Nissim, D., 2011, Relative valuation of U.S. insurance companies, Review of Accounting Studies, forthcoming.

Norton, E., H, Wang, and C. Ai, 2004, Computing interaction effects and standard errors in logit and probit models, The STATA Journal 4, 154-167.

Penman, S. H., 2007, Financial reporting quality: Is fair value a plus or a minus? Accounting and Business Research Special Issue: International Accounting Policy Forum, 33-44.

Petroni, K.R., and J.M. Wahlen, 1995, Fair values of equity and debt securities and share prices of property-liability insurers, Journal of Risk and Insurance, 62, 719-737.

Plantin, G., H. Sapra, and H. Shin, 2008, Marking-to-market: Panacea or Pandora's box? Journal of Accounting Research 46, 435-460.

Sapra, H., 2008, Do accounting measurement regimes matter? A discussion of mark-to-market accounting and liquidity pricing, Journal of Accounting and Economics 45, 379-387.

Scheve, K. F., and M. J. Slaughter, 1999, What determines individual trade-policy preferences? NBER working paper.

Scholes, M. S., G. P. Wilson, and M. A. Wolfson, 1990, Tax planning, regulatory capital planning, and financial reporting strategy for commercial banks, Review of Financial Studies 3, 625-650.

Schultz, P., 2001, Corporate bond trading costs: A peek behind the curtain, Journal of Finance 56, 677-698.

SEC, 2011, 2011 Summary Report of Commission Staff's examinations of each nationally recognized statistical rating organization, U.S. Securities and Exchange Commission, September 2011.

Veron, N., 2008, Fair value accounting is the wrong scapegoat for this crisis, European Accounting Review 5, 63-69.

Wallison, P.J., 2008, Fair value accounting: A critique, Financial Services Outlook, American Enterprise Institute for Public Policy Research, July 2008.

Wyatt, A. (1991). The SEC says: mark to market! Accounting Horizons 5, 80-84. 


\section{Appendix A: Descriptions of Variables}

\begin{tabular}{|c|c|c|}
\hline Variable & Specific to & Definition \\
\hline \% risky assets & Insurer-year & $\begin{array}{l}\text { Percentage of investment assets invested in any of the following asset classes: non- } \\
\text { investment grade bonds, common and preferred stocks, non-performing mortgages, } \\
\text { real estate, and other investments. According to the Street.com and NAIC, the } \\
\text { target capital percentages for these assets are greater than or equal to those of the } \\
\text { least risky class of non-investment grade bonds (BB). }\end{array}$ \\
\hline ABS exposure & Insurer-year & $\begin{array}{l}\text { Percentage of bond portfolio invested in asset-backed securities (ABS) held at book } \\
\text { value, measured in market value terms. Securities (9-digit CUSIPs) are classified } \\
\text { as ABS, based on the list of rated securities from S\&P's RatingIquery. High ABS } \\
\text { exposure dummy equals } 1 \text { for ABS exposures above the annual median, and } 0 \\
\text { otherwise. }\end{array}$ \\
\hline $\begin{array}{l}\text { Bankruptcy } \\
\text { dummy }\end{array}$ & Bond-quarter & $\begin{array}{l}\text { Dummy variable equal to } 1 \text { if the issuer of the bond files for bankruptcy during the } \\
\text { quarter, and } 0 \text { otherwise. }\end{array}$ \\
\hline Bond age & Bond-quarter & $\begin{array}{l}\text { Time from issuance to the beginning of quarter of interest or the beginning of } \\
\text { quarter in which the interested transactions fall (depending on specifications), } \\
\text { measured in years. }\end{array}$ \\
\hline Bond return & Bond-quarter & $\begin{array}{l}\text { Log of change in prices from the last day when there are any trades of a bond in the } \\
\text { previous quarter to the last day in the current quarter, scaled by a factor of } 100 . \\
\text { Abnormal bond return is calculated as the residual of pooled OLS regression of } \\
\text { bond return on maturity matched treasury return and maturity- and rating-matched } \\
\text { corporate bond index return over the same quarter. Corporate bond index return is } \\
\text { calculated using Bank of America-Merrill Lynch bond index, adjusted for duration } \\
\text { difference between the index and the bond of interest. }\end{array}$ \\
\hline $\begin{array}{l}\text { Calendar quarter } \\
\text { fixed effects }\end{array}$ & Quarter & Set of dummy variables for calendar quarters in which the observations fall. \\
\hline $\begin{array}{l}\text { Capital and } \\
\text { surplus }\end{array}$ & Insurer-year & $\begin{array}{l}\text { The insurance company's statutory net worth (including paid-in capital or } \\
\text { unimpaired surplus and additional funds in surplus) in millions of dollars through } \\
\text { the most recent year end. }\end{array}$ \\
\hline Crisis dummy & Quarter & $\begin{array}{l}\text { Dummy variable equal to } 1 \text { if the calendar quarters are in the } 2007-2009 \text { crisis } \\
\text { period, and } 0 \text { otherwise. The crisis period is defined based on the volume of ABS } \\
\text { downgrades, and covers } 2007 \mathrm{Q} 3 \text { to } 2009 \mathrm{Q} \text {. }\end{array}$ \\
\hline $\begin{array}{l}\text { Downgrade } \\
\text { dummy }\end{array}$ & Bond-quarter & $\begin{array}{l}\text { Dummy variable equal to } 1 \text { if the bond is downgraded from investment to non- } \\
\text { investment grades during the quarter, and } 0 \text { otherwise. S\&P ratings are used } \\
\text { wherever available. Moody's ratings are used when S\&P ratings are unavailable. }\end{array}$ \\
\hline $\begin{array}{l}\text { Incremental effect } \\
\text { of unrealized gain } \\
\text { on selling } \\
\text { probability }\end{array}$ & $\begin{array}{l}\text { Position- } \\
\text { quarter or } \\
\text { Bond-quarter }\end{array}$ & $\begin{array}{l}\text { Position-quarter incremental effect of unrealized gain on selling probability is } \\
\text { predicted value for each bond position (relative to mean) obtained from the logit } \\
\text { model similar to model (2) in Table } 8 \text {, estimated separately for each calendar } \\
\text { quarter. Bond-quarter incremental effect of unrealized gain on selling probability } \\
\text { is value-weighted or equally-weighted average of position-quarter incremental } \\
\text { effects, where the average is taken across all insurers holding the bond at the } \\
\text { beginning of the quarter. }\end{array}$ \\
\hline Issue size & Bond & Offering amount of the bond, measured in million dollars. \\
\hline Leverage & Insurer-year & Debt as percentage of total assets, all measured at book values. \\
\hline $\begin{array}{l}\text { Liquidity index } \\
*, * *\end{array}$ & Insurer-year & $\begin{array}{l}\text { The Street.com's index that measures the insurance company's ability to raise cash } \\
\text { to settle claims. The inability to raise cash may arise when the company is owed a } \\
\text { great deal of money from its agents or reinsurers, or it cannot sell its investments at } \\
\text { the prices at which the investments are valued in the company's financial } \\
\text { statements. Low liquidity index dummy equals } 1 \text { for liquidity index values below } \\
5 \text {, and } 0 \text { otherwise. }\end{array}$ \\
\hline Maturity & Bond-quarter & $\begin{array}{l}\text { Maturity of the bond at the beginning of quarter of interest or the beginning of } \\
\text { quarter in which the interested transactions fall (depending on specifications), } \\
\text { measured in years. }\end{array}$ \\
\hline NAIC risk-based & Insurer-year & Ratio of total adjusted capital (capital, surplus, and applicable valuation reserves) \\
\hline
\end{tabular}




\begin{tabular}{|c|c|c|}
\hline Variable & Specific to & Definition \\
\hline $\begin{array}{l}\text { capital ratio (RBC } \\
\text { Ratio) }\end{array}$ & & $\begin{array}{l}\text { to NAIC risk-based capital (RBC). RBC is the minimum amount of capital that the } \\
\text { insurance company must maintain based on the inherent risks in its operations. } \\
\text { RBC is calculated based on the NAIC's formula which reflects its assessment of } \\
\text { risks of different asset classes and businesses. For example, a company with RBC } \\
\text { ratio of } 1.0 \text { has capital equal to its RBC. Insurance companies with higher RBC } \\
\text { ratios are considered better capitalized. Insurance companies with RBC ratio } \\
\text { below } 2.0 \text { are subject to supervisory interventions. The levels of supervisory } \\
\text { actions depend on the level of RBC ratio. Low RBC ratio dummy equals } 1 \text { for } \\
\text { RBC ratios below the annual median, and } 0 \text { otherwise. }\end{array}$ \\
\hline $\begin{array}{l}\text { Rating group fixed } \\
\text { effects }\end{array}$ & Bond-quarter & $\begin{array}{l}\text { Set of dummy variables for credit rating groups, defined by the NAIC's capital } \\
\text { requirement in the RBC ratio formula. The groups are, in order of credit quality, A } \\
\text { and above, BBB, BB, and B and below. S\&P ratings are used wherever available. } \\
\text { Moody’s ratings are used when S\&P ratings are unavailable. }\end{array}$ \\
\hline Revalue dummy & Position-year & $\begin{array}{l}\text { Dummy variable equal to } 1 \text { if the position has the book value that is equal to its } \\
\text { reported fair or market value, and } 0 \text { otherwise. }\end{array}$ \\
\hline ROE & Insurer-year & $\begin{array}{l}\text { Return on equity, measured as net income divided by book value of equity at the } \\
\text { beginning of the year. Positive ROE dummy equals } 1 \text { if ROE is greater than zero, } \\
\text { and } 0 \text { otherwise. }\end{array}$ \\
\hline $\begin{array}{l}\text { Sell dummy } \\
\text { (dependent } \\
\text { variable in logit) }\end{array}$ & $\begin{array}{l}\text { Position- } \\
\text { quarter }\end{array}$ & $\begin{array}{l}\text { Dummy variable equal to } 1 \text { if part or all of the position is sold during the quarter, } \\
\text { and } 0 \text { otherwise. }\end{array}$ \\
\hline Selling probability & $\begin{array}{l}\text { Position- } \\
\text { quarter or } \\
\text { Bond-quarter }\end{array}$ & $\begin{array}{l}\text { Position-quarter selling probability is predicted selling probability for each bond } \\
\text { position obtained from the logit model similar to model (2) in Table 8, estimated } \\
\text { separately for each calendar quarter. Bond-quarter selling probability is value- } \\
\text { weighted or equally-weighted average of position-quarter selling probabilities, } \\
\text { where the average is taken across all insurers holding the bond at the beginning of } \\
\text { the quarter. }\end{array}$ \\
\hline State fixed effects & Insurer-year & Set of dummy variables for insurers’ domicile states. \\
\hline $\begin{array}{l}\text { Unrealized gain } \\
\text { (and loss) }\end{array}$ & Position-year & $\begin{array}{l}\text { Difference between insurer's reported fair value and book-adjusted carrying value } \\
\text { of the position at previous year end, measured as percentage of book value. } \\
\text { Unrealized gain percentile is the percentile rank, ranging from } 0 \text { to } 1 \text {, of the } \\
\text { position's dollar unrealized gain within the insurer's portfolio at previous year end. }\end{array}$ \\
\hline
\end{tabular}

* The Street.com may not evaluate some insurance companies for one or more of the following reasons: (i) total assets are less than $\$ 1$ million, (ii) premium income for the current year is less than $\$ 100,000$, (iii) the company functions almost exclusively as a holding company rather than as an underwriter, or (iv) the Street.com does not have enough information to reliably evaluate the company.

** Scores range from 1 to 10 . Scores of 7 to 10,5 to 6.9, 3 to 4.9, and 2.9 and below are considered "strong", "good", "fair", and "weak", respectively. 


\section{Table 1: Summary Statistics of Insurance Companies}

This table presents descriptive characteristics of all insurance firms in our sample at the end of 2007. Our sample restrict to insurance companies with invested assets not less than \$13 million and RBC ratio between 2 and 20. We also exclude 33 bond insurers including AIG, AMBAC, MBIA, etc. Definition of the variables can be found in the Appendix A.

\section{Panel A: Life Firms}

\begin{tabular}{lrrrrr}
\hline & Mean & 10thPct & 50thPct & 90thPct & Std.Dev. \\
\hline Number of Firms & 432 & & & & \\
Invested Assets (\$ million) & 5,759 & 33 & 510 & 12,163 & 18,376 \\
Capital and Surplus (\$ million) & 554 & 8 & 81 & 1,426 & 1,462 \\
Leverage & 0.83 & 0.63 & 0.89 & 0.96 & 0.17 \\
Return on Equity (ROE) & 0.09 & -0.06 & 0.09 & 0.26 & 0.25 \\
NAIC Risk-Based Capital Ratio (RBC ratio) & 9.14 & 4.75 & 8.37 & 14.90 & 3.84 \\
Holding of Investment-Grade Bonds (\%) & 55.00 & 31.10 & 55.05 & 80.90 & 20.30 \\
Holding of Risky Assets (\%) & 16.90 & 2.94 & 11.97 & 33.97 & 16.82 \\
Profitability Index & 5.66 & 1.90 & 6.20 & 8.40 & 2.34 \\
Liquidity Index & 6.58 & 4.90 & 6.70 & 9.00 & 1.73 \\
\hline
\end{tabular}

Panel B: Property and Casualty Firms

\begin{tabular}{lrrrrr}
\hline & Mean & 10thPct & 50thPct & 90thPct & Std.Dev. \\
\hline Number of Firms & 1,344 & & & & \\
Invested Assets (\$ million) & 829 & 22 & 119 & 1,272 & 3,996 \\
Capital and Surplus (\$ million) & 384 & 11 & 53 & 565 & 2,172 \\
Leverage & 0.60 & 0.42 & 0.62 & 0.75 & 0.14 \\
Return on Equity (ROE) & 0.12 & 0.01 & 0.11 & 0.25 & 0.13 \\
NAIC Risk-Based Capital Ratio (RBC ratio) & 8.26 & 3.70 & 7.40 & 14.00 & 3.94 \\
Holding of Investment-Grade Bonds (\%) & 63.16 & 35.72 & 64.19 & 91.13 & 21.45 \\
Holding of Risky Assets (\%) & 17.51 & 0.00 & 12.05 & 41.86 & 19.40 \\
Profitability Index & 6.31 & 3.30 & 6.50 & 8.80 & 2.07 \\
Liquidity Index & 6.76 & 5.70 & 6.80 & 8.30 & 1.40 \\
\hline
\end{tabular}




\section{Table 2: Summary Statistics of Insurance Companies’ Holding of ABS Securities}

This table summarizes the holding of ABS securities of insurance companies at year-end. We identify ABS positions by matching insurance firms' bond holding positions at year-end to a list of ABS securities identified from S\&P's Ratings IQuery using 9-digit CUSIP. S\&P's Ratings IQuery comprehensively covers initial ratings and histories for all securitized issues rated by S\&P from 1991 to 2010 . The statistics on the number and size of ABS holdings are reported only for firms investing in ABS. The size of the ABS holdings is the par (or fair) value of the identified ABS securities held by a firm relative to the par (or fair) value of all fixed income positions in this firm. We report the mean, median, top, and bottom percentile across firms at each year-end.

\begin{tabular}{|c|c|c|c|c|c|c|c|c|c|c|c|c|c|c|c|}
\hline & \multirow[b]{2}{*}{ Year } & \multicolumn{2}{|c|}{$\begin{array}{l}\text { Number of } \\
\text { insurance } \\
\text { firms }\end{array}$} & \multicolumn{4}{|c|}{$\begin{array}{l}\text { Number of ABS securities } \\
\text { held by each firm }\end{array}$} & \multicolumn{4}{|c|}{$\begin{array}{l}\% \text { ABS holding in all bond } \\
\text { positions (par value) }\end{array}$} & \multicolumn{4}{|c|}{$\begin{array}{c}\% \text { ABS holding in all bond } \\
\text { positions (fair value) }\end{array}$} \\
\hline & & All & $\begin{array}{l}\text { Firms } \\
\text { holding } \\
\text { ABS }\end{array}$ & Mean & $\begin{array}{l}\text { 10th } \\
\text { Pct }\end{array}$ & Median & $\begin{array}{l}\text { 90th } \\
\text { Pct }\end{array}$ & Mean & $\begin{array}{l}\text { 10th } \\
\text { Pct }\end{array}$ & Median & $\begin{array}{l}\text { 90th } \\
\text { Pct }\end{array}$ & Mean & $\begin{array}{l}\text { 10th } \\
\text { Pct }\end{array}$ & Median & $\begin{array}{l}\text { 90th } \\
\text { Pct }\end{array}$ \\
\hline \multirow{7}{*}{ Life } & 2004 & 496 & 399 & 36.42 & 1 & 11 & 93 & $4.74 \%$ & $0.57 \%$ & $3.45 \%$ & $9.26 \%$ & $4.63 \%$ & $0.56 \%$ & $3.52 \%$ & $9.39 \%$ \\
\hline & 2005 & 474 & 396 & 47.86 & 1 & 12 & 112 & $5.16 \%$ & $0.63 \%$ & $4.14 \%$ & $10.99 \%$ & $5.14 \%$ & $0.66 \%$ & $4.19 \%$ & $10.99 \%$ \\
\hline & 2006 & 454 & 385 & 61.84 & 2 & 15 & 148 & $6.60 \%$ & $0.65 \%$ & $5.04 \%$ & $14.23 \%$ & $6.58 \%$ & $0.70 \%$ & $5.12 \%$ & $14.15 \%$ \\
\hline & 2007 & 432 & 363 & 75.15 & 2 & 18 & 200 & $7.65 \%$ & $0.76 \%$ & $6.17 \%$ & $16.30 \%$ & $7.26 \%$ & $0.75 \%$ & $5.98 \%$ & $15.13 \%$ \\
\hline & 2008 & 424 & 353 & 79.13 & 2 & 18 & 221 & $7.79 \%$ & $0.69 \%$ & $6.20 \%$ & $16.54 \%$ & $5.76 \%$ & $0.59 \%$ & $4.64 \%$ & $12.05 \%$ \\
\hline & 2009 & 414 & 345 & 76.06 & 2 & 17 & 224 & $6.90 \%$ & $0.52 \%$ & $5.19 \%$ & $14.24 \%$ & $5.15 \%$ & $0.47 \%$ & $3.86 \%$ & $10.80 \%$ \\
\hline & 2010 & 412 & 330 & 70.75 & 1 & 15 & 204 & $5.68 \%$ & $0.40 \%$ & $4.61 \%$ & $11.80 \%$ & $4.47 \%$ & $0.37 \%$ & $3.65 \%$ & $9.20 \%$ \\
\hline \multirow{7}{*}{$\begin{array}{c}\text { Property } \\
\& \\
\text { Casualty }\end{array}$} & 2004 & 1,307 & 778 & 7.70 & 1 & 5 & 17 & $4.06 \%$ & $0.54 \%$ & $3.33 \%$ & $8.40 \%$ & $4.05 \%$ & $0.54 \%$ & $3.26 \%$ & $8.54 \%$ \\
\hline & 2005 & 1,320 & 813 & 9.11 & 1 & 5 & 19 & $4.42 \%$ & $0.60 \%$ & $3.21 \%$ & $8.78 \%$ & $4.42 \%$ & $0.59 \%$ & $3.21 \%$ & $8.78 \%$ \\
\hline & 2006 & 1,313 & 831 & 10.77 & 1 & 6 & 23 & $5.12 \%$ & $0.52 \%$ & $3.70 \%$ & $11.57 \%$ & $5.08 \%$ & $0.53 \%$ & $3.64 \%$ & $11.22 \%$ \\
\hline & 2007 & 1,344 & 864 & 11.99 & 1 & 7 & 26 & $5.49 \%$ & $0.61 \%$ & $3.79 \%$ & $11.59 \%$ & $5.26 \%$ & $0.56 \%$ & $3.70 \%$ & $11.21 \%$ \\
\hline & 2008 & 1,390 & 857 & 11.99 & 1 & 6 & 26 & $4.88 \%$ & $0.54 \%$ & $3.13 \%$ & $10.77 \%$ & $3.70 \%$ & $0.43 \%$ & $2.38 \%$ & $8.08 \%$ \\
\hline & 2009 & 1,390 & 813 & 10.66 & 1 & 4 & 22 & $3.62 \%$ & $0.30 \%$ & $2.17 \%$ & $7.85 \%$ & $2.75 \%$ & $0.27 \%$ & $1.73 \%$ & $6.12 \%$ \\
\hline & 2010 & 1,385 & 673 & 8.42 & 1 & 3 & 18 & $2.95 \%$ & $0.23 \%$ & $1.59 \%$ & $6.95 \%$ & $2.35 \%$ & $0.19 \%$ & $1.29 \%$ & $5.37 \%$ \\
\hline
\end{tabular}


Table 3: Ratings Downgrades of ABS Securities Held by Insurance Companies

This table reports the ratings transitions of ABS securities that are held by life or P\&C insurance companies and are downgraded by S\&P during the financial crisis (defined as the period from the third quarter of 2007 to the end of 2009). The downgraded securities are grouped by the ratings before and after the downgrade. For example, 714 different ABS securities are downgraded directly from AAA to B.

\begin{tabular}{|c|c|c|c|c|c|c|c|c|c|c|c|c|}
\hline & & & & & ating $A$ & er Dow & grade & & & & & \\
\hline & & AA & A & BBB & BB & B & $\mathrm{CCC}$ & $\mathrm{CC}$ & $\mathrm{C}$ & $\mathrm{D}$ & Total & $\%$ of Total \\
\hline & AAA & 935 & 660 & 569 & 451 & 714 & 129 & 7 & 0 & 2 & 3,467 & $40.1 \%$ \\
\hline & AA & & 445 & 327 & 129 & 159 & 131 & 21 & 0 & 0 & 1,212 & $14.0 \%$ \\
\hline 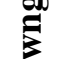 & A & & & 568 & 266 & 223 & 204 & 34 & 0 & 1 & 1,296 & $15.0 \%$ \\
\hline อ̊ & $\mathrm{BBB}$ & & & & 392 & 276 & 306 & 79 & 0 & 5 & 1,058 & $12.2 \%$ \\
\hline 0 & BB & & & & & 267 & 307 & 58 & 0 & 0 & 632 & $7.3 \%$ \\
\hline 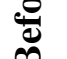 & B & & & & & & 510 & 95 & 0 & 2 & 607 & $7.0 \%$ \\
\hline 20 & CCC & & & & & & & 339 & 3 & 19 & 361 & $4.2 \%$ \\
\hline$\vec{\nabla}$ & CC & & & & & & & & 0 & 10 & 10 & $0.1 \%$ \\
\hline & C & & & & & & & & & 3 & 3 & $0.0 \%$ \\
\hline & Total & 935 & 1,105 & 1,464 & 1,238 & 1,639 & 1,587 & 633 & 3 & 42 & 8,646 & $100.0 \%$ \\
\hline$\% 0$ & Total & $10.8 \%$ & $12.8 \%$ & $16.9 \%$ & $14.3 \%$ & $19.0 \%$ & $18.4 \%$ & $7.3 \%$ & $0.0 \%$ & $0.5 \%$ & $100.0 \%$ & \\
\hline
\end{tabular}




\section{Table 4: Accounting Treatment of Downgraded ABS}

This table reports frequency statistics on insurance companies' accounting treatment of downgraded ABS that are previously held at modified historical costs. Two types of downgrade are considered: (a) from investment to non-investment grades and (b) from AAA to non-investment grade. Rows 1 and 2 include all downgrades from 2005 to 2010, and rows 3 and 4 include only the downgrades in the fourth quarter of each year. Over the year in which the downgrade occurs, each position held at historical cost at the beginning of year is reclassified into one of the following three groups: (i) kept at historical cost (HCA), (ii) kept but revalued to the year-end fair value, and (iii) sold. The percentages of these groups are reported separately for each type of downgrade and for life and P\&C insurance companies.

\begin{tabular}{|c|c|c|c|c|c|c|c|c|}
\hline & \multicolumn{4}{|c|}{ Life } & \multicolumn{4}{|c|}{ Property \& Casualty } \\
\hline & \multirow[b]{2}{*}{$\begin{array}{c}\text { Total } \\
\text { Number }\end{array}$} & \multicolumn{3}{|c|}{ Treatment after Downgrade } & \multirow[b]{2}{*}{$\begin{array}{c}\text { Total } \\
\text { Number }\end{array}$} & \multicolumn{3}{|c|}{ Treatment after Downgrade } \\
\hline & & HCA & Revalued & Sold & & HCA & Revalued & Sold \\
\hline \multicolumn{9}{|l|}{ All downgrades in 2005-2010 } \\
\hline $\begin{array}{l}\text { 1. Investment to non- } \\
\text { investment }\end{array}$ & 5,161 & $71 \%$ & $15 \%$ & $14 \%$ & 1,588 & $40 \%$ & $39 \%$ & $21 \%$ \\
\hline 2. AAA to non-investment & 1,860 & $79 \%$ & $9 \%$ & $12 \%$ & 851 & $45 \%$ & $36 \%$ & $20 \%$ \\
\hline \multicolumn{9}{|c|}{ All downgrades in the fourth quarter } \\
\hline $\begin{array}{l}\text { 3. Investment to non- } \\
\text { investment }\end{array}$ & 1,207 & $74 \%$ & $14 \%$ & $13 \%$ & 327 & $20 \%$ & $60 \%$ & $20 \%$ \\
\hline 4. AAA to non-investment & 514 & $79 \%$ & $10 \%$ & $11 \%$ & 220 & $16 \%$ & $63 \%$ & $20 \%$ \\
\hline
\end{tabular}




\section{Table 5: Summary Statistics of Unrealized Gains/Losses of ABS and Corporate Bond Positions}

This table presents descriptive statistics on the distribution of unrealized gains/losses on ABS (Panel A) and corporate bonds (Panel B) held by life and $\mathrm{P} \& \mathrm{C}$ insurance companies. For each bond position, unrealized gain is the difference between the position's reported fair value and bookadjusted carrying value, measured as a percentage of book-adjusted carrying value.

Panel A: Unrealized Gains/Losses of ABS

\begin{tabular}{|c|c|c|c|c|c|c|c|c|c|c|c|c|}
\hline \multirow[b]{2}{*}{ Year } & \multicolumn{6}{|c|}{ Life } & \multicolumn{6}{|c|}{ Property and Casualty } \\
\hline & $\begin{array}{c}\text { \# of } \\
\text { Positions }\end{array}$ & 10thPct & 25thPct & 50thPct & 75thPct & 90thPct & $\begin{array}{c}\text { \# of } \\
\text { Positions }\end{array}$ & 10thPct & 25thPct & 50thPct & 75thPct & 90thPct \\
\hline 2004 & 13,494 & $-1.4 \%$ & $-0.2 \%$ & $0.9 \%$ & $4.4 \%$ & $10.1 \%$ & 5,642 & $-1.7 \%$ & $-0.8 \%$ & $0.0 \%$ & $1.8 \%$ & $5.9 \%$ \\
\hline 2005 & 17,785 & $-3.3 \%$ & $-1.8 \%$ & $-0.1 \%$ & $1.0 \%$ & $5.3 \%$ & 7,072 & $-3.2 \%$ & $-2.0 \%$ & $-0.7 \%$ & $0.1 \%$ & $1.8 \%$ \\
\hline 2006 & 22,270 & $-2.7 \%$ & $-1.1 \%$ & $0.0 \%$ & $1.0 \%$ & $3.8 \%$ & 8,508 & $-2.7 \%$ & $-1.4 \%$ & $-0.2 \%$ & $0.2 \%$ & $1.4 \%$ \\
\hline 2007 & 26,754 & $-17.1 \%$ & $-8.0 \%$ & $-2.1 \%$ & $0.2 \%$ & $2.9 \%$ & 9,886 & $-7.4 \%$ & $-1.7 \%$ & $-0.3 \%$ & $0.6 \%$ & $1.9 \%$ \\
\hline 2008 & 26,476 & $-75.3 \%$ & $-55.7 \%$ & $-30.8 \%$ & $-8.8 \%$ & $-0.3 \%$ & 8,416 & $-54.6 \%$ & $-31.9 \%$ & $-12.1 \%$ & $-1.9 \%$ & $0.0 \%$ \\
\hline 2009 & 24,091 & $-60.9 \%$ & $-38.3 \%$ & $-16.4 \%$ & $-0.2 \%$ & $7.4 \%$ & 6,733 & $-35.4 \%$ & $-15.0 \%$ & $-1.5 \%$ & $1.7 \%$ & $9.5 \%$ \\
\hline 2010 & 20,418 & $-36.5 \%$ & $-18.8 \%$ & $-2.8 \%$ & $4.7 \%$ & $23.3 \%$ & 4,281 & $-16.0 \%$ & $-4.0 \%$ & $1.4 \%$ & $6.9 \%$ & $28.5 \%$ \\
\hline
\end{tabular}

Panel B: Unrealized Gains/Losses of Corporate Bonds

\begin{tabular}{|c|c|c|c|c|c|c|c|c|c|c|c|c|}
\hline \multirow[b]{2}{*}{ Year } & \multicolumn{6}{|c|}{ Life } & \multicolumn{6}{|c|}{ Property and Casualty } \\
\hline & $\begin{array}{c}\text { \# of } \\
\text { Positions }\end{array}$ & 10thPct & 25thPct & 50thPct & 75thPct & 90thPct & $\begin{array}{c}\text { \# of } \\
\text { Positions }\end{array}$ & 10thPct & 25thPct & 50thPct & 75thPct & 90thPct \\
\hline 2004 & 142,626 & $-0.8 \%$ & $0.9 \%$ & $4.1 \%$ & $9.5 \%$ & $15.5 \%$ & 69,897 & $-1.3 \%$ & $-0.1 \%$ & $2.0 \%$ & $6.4 \%$ & $11.6 \%$ \\
\hline 2005 & 143,492 & $-3.5 \%$ & $-1.6 \%$ & $0.7 \%$ & $5.1 \%$ & $11.1 \%$ & 67,288 & $-3.4 \%$ & $-2.2 \%$ & $-0.5 \%$ & $2.2 \%$ & $7.0 \%$ \\
\hline 2006 & 136,579 & $-3.9 \%$ & $-1.9 \%$ & $0.2 \%$ & $3.4 \%$ & $8.2 \%$ & 66,790 & $-3.5 \%$ & $-2.2 \%$ & $-0.3 \%$ & $1.6 \%$ & $5.3 \%$ \\
\hline 2007 & 135,159 & $-6.8 \%$ & $-2.6 \%$ & $0.1 \%$ & $2.8 \%$ & $7.0 \%$ & 63,947 & $-3.6 \%$ & $-1.1 \%$ & $0.3 \%$ & $2.1 \%$ & $4.8 \%$ \\
\hline 2008 & 133,204 & $-31.6 \%$ & $-18.1 \%$ & $-6.6 \%$ & $0.0 \%$ & $4.9 \%$ & 63,542 & $-17.7 \%$ & $-7.6 \%$ & $-1.8 \%$ & $1.0 \%$ & $4.5 \%$ \\
\hline 2009 & 128,304 & $-6.1 \%$ & $-0.1 \%$ & $4.2 \%$ & $7.8 \%$ & $13.1 \%$ & 69,066 & $-0.5 \%$ & $1.8 \%$ & $4.7 \%$ & $7.6 \%$ & $11.9 \%$ \\
\hline 2010 & 115,007 & $-0.8 \%$ & $2.7 \%$ & $7.1 \%$ & $11.8 \%$ & $17.4 \%$ & 61,337 & $0.3 \%$ & $2.4 \%$ & $6.3 \%$ & $10.4 \%$ & $14.9 \%$ \\
\hline
\end{tabular}




\section{Table 6: Probability of Revaluing ABS to Year-End Fair Value}

This table reports logit estimates for the probability that an insurance company revalues its ABS position to the year-end fair value. The dependent variable is a dummy that equals one if the insurance company revalues the ABS, and zero otherwise. Each observation is positionyear, and the sample includes all ABS positions from 2004 year-end to 2010 year-end. Panel A reports the coefficient estimates. Panel B reports the marginal effects of being a P\&C insurance company (over being a life company), evaluated for (i) the crisis vs. non-crisis periods and (ii) the ABS being downgraded from investment to non-investment grades vs. not downgraded during the year. All other variables are held at the sample means. Standard errors, clustered by insurance company, are in parentheses. ${ }^{*}, * *$, and $* * *$ refer to statistical significance at $10 \%$, $5 \%$, and $1 \%$ levels. Variable definitions are in Appendix A.

Panel A: Coefficient Estimates

\begin{tabular}{|c|c|c|c|c|c|c|c|c|}
\hline & $\begin{array}{c}(1) \\
\text { Non-Crisis } \\
\end{array}$ & $\begin{array}{c}(2) \\
\text { Crisis } \\
\end{array}$ & $\begin{array}{c}(3) \\
\text { Non-Crisis }\end{array}$ & $\begin{array}{l}(4) \\
\text { Crisis } \\
\end{array}$ & $\begin{array}{l}(5) \\
\text { All } \\
\end{array}$ & $\begin{array}{l}\text { (6) } \\
\text { All } \\
\end{array}$ & $\begin{array}{l}(7) \\
\text { All }\end{array}$ & $\begin{array}{l}(8) \\
\text { All }\end{array}$ \\
\hline $\mathrm{P} \& \mathrm{C}$ dummy & $\begin{array}{c}0.324 \\
(0.253)\end{array}$ & $\begin{array}{c}1.484 * * * \\
(0.146)\end{array}$ & $\begin{array}{c}0.514^{* *} \\
(0.220)\end{array}$ & $\begin{array}{c}1.643 * * * \\
(0.163)\end{array}$ & $\begin{array}{l}0.329 \\
(0.258)\end{array}$ & $\begin{array}{c}0.352 \\
(0.290)\end{array}$ & $\begin{array}{c}0.527 * * \\
(0.235)\end{array}$ & $\begin{array}{c}0.570^{* *} \\
(0.263)\end{array}$ \\
\hline Downgrade dummy & & & $\begin{array}{c}0.076 \\
(0.311)\end{array}$ & $\begin{array}{c}0.368^{* * *} \\
(0.114)\end{array}$ & & & $\begin{array}{c}0.707 * * * \\
(0.168)\end{array}$ & $\begin{array}{c}0.654^{* * *} \\
(0.133)\end{array}$ \\
\hline P\&C dummy x Downgrade dummy & & & $\begin{array}{c}2.024 * * * \\
(0.453)\end{array}$ & $\begin{array}{c}0.317^{* *} \\
(0.165)\end{array}$ & & & $\begin{array}{c}0.444^{* *} \\
(0.178)\end{array}$ & $\begin{array}{c}0.421^{* *} \\
(0.172)\end{array}$ \\
\hline Crisis dummy & & & & & $\begin{array}{l}-0.501 \\
(0.319)\end{array}$ & & $\begin{array}{l}-0.581^{*} \\
(0.332)\end{array}$ & \\
\hline P\&C dummy x Crisis dummy & & & & & $\begin{array}{c}1.064^{* * *} \\
(0.304)\end{array}$ & $\begin{array}{c}1.069 * * * \\
(0.347)\end{array}$ & $\begin{array}{c}1.011^{* * *} \\
(0.309)\end{array}$ & $\begin{array}{c}0.998 * * * \\
(0.345)\end{array}$ \\
\hline $\ln$ (maturity) & & & $\begin{array}{c}0.276 * * * \\
(0.059)\end{array}$ & $\begin{array}{c}0.431^{* * *} \\
(0.058)\end{array}$ & & & $\begin{array}{c}0.313^{* * *} \\
(0.047)\end{array}$ & $\begin{array}{c}0.343^{* * *} \\
(0.048)\end{array}$ \\
\hline $\ln ($ issue size) & & & $\begin{array}{c}-0.202 * * * \\
(0.026)\end{array}$ & $\begin{array}{c}-0.259 * * * \\
(0.027)\end{array}$ & & & $\begin{array}{c}-0.217 * * * \\
(0.022)\end{array}$ & $\begin{array}{c}-0.232 * * * \\
(0.020)\end{array}$ \\
\hline Rating group fixed effects & YES & YES & YES & YES & YES & YES & YES & YES \\
\hline State fixed effects & YES & YES & YES & YES & YES & YES & YES & YES \\
\hline Year fixed effects & YES & YES & YES & YES & NO & YES & NO & YES \\
\hline $\begin{array}{l}\text { Observations } \\
\text { Pseudo R-squared }\end{array}$ & $\begin{array}{c}95,507 \\
0.105\end{array}$ & $\begin{array}{c}97,829 \\
0.225\end{array}$ & $\begin{array}{c}95,507 \\
0.123\end{array}$ & $\begin{array}{c}97,829 \\
0.250\end{array}$ & $\begin{array}{c}193,336 \\
0.135\end{array}$ & $\begin{array}{c}193,336 \\
0.154\end{array}$ & $\begin{array}{c}193,336 \\
0.157\end{array}$ & $\begin{array}{c}193,336 \\
0.178\end{array}$ \\
\hline
\end{tabular}


Table 6, cont'd: Probability of Revaluing ABS to Year-End Fair Value

Panel B: Marginal Effects of P\&C Dummy

\begin{tabular}{|c|c|c|c|c|c|c|c|c|}
\hline & $\begin{array}{c}(1) \\
\text { Non-Crisis }\end{array}$ & $\begin{array}{c}(2) \\
\text { Crisis } \\
\end{array}$ & $\begin{array}{c}(3) \\
\text { Non-Crisis }\end{array}$ & $\begin{array}{c}(4) \\
\text { Crisis } \\
\end{array}$ & $\begin{array}{l}(5) \\
\text { All }\end{array}$ & $\begin{array}{l}\text { (6) } \\
\text { All }\end{array}$ & $\begin{array}{l}\text { (7) } \\
\text { All }\end{array}$ & $\begin{array}{l}\text { (8) } \\
\text { All }\end{array}$ \\
\hline Crisis dummy $=0$ & 0.019 & & & & 0.019 & 0.019 & & \\
\hline Crisis dummy $=1$ & & $0.082 * * *$ & & & $0.082^{* * *}$ & $0.081^{* * *}$ & & \\
\hline Crisis dummy $=0$ and Downgrade dummy $=0$ & & & $0.027^{*}$ & & & & $0.026^{* *}$ & $0.026 * *$ \\
\hline Crisis dummy $=0$ and Downgrade dummy $=1$ & & & $0.142^{* *}$ & & & & $0.087 * * *$ & $0.080 * * *$ \\
\hline Crisis dummy $=1$ and Downgrade dummy $=0$ & & & & $0.070 * * *$ & & & $0.068 * * *$ & $0.066^{* * *}$ \\
\hline Crisis dummy $=1$ and Downgrade dummy $=1$ & & & & $0.125^{* * *}$ & & & $0.167 * * *$ & $0.163 * * *$ \\
\hline
\end{tabular}




\section{Table 7: Probability of Selling Downgraded ABS}

This table reports logit estimates for the probability that an insurance company sells its downgraded ABS within 3 months after the downgrade. The first two columns include all downgrades. Columns (3) and (4) include only the downgrades from investment to non-investment grades. Columns (5) and (6) include only the downgrades from AAA to non-investment grade. Panel A reports the coefficient estimates. Panel B reports the marginal effects of (i) the company being a P\&C insurance company (over being a life company) and (ii) the position being revalued by the company at previous year-end. All other variables are held at the sample means. Standard errors, clustered by insurance company, are in parentheses. *, **, and *** refer to statistical significance at 10\%, 5\%, and $1 \%$ levels. Variable definitions are in Appendix A.

\begin{tabular}{|c|c|c|c|c|c|c|}
\hline & $\begin{array}{c}(1) \\
\text { All } \\
\text { Downgrades }\end{array}$ & $\begin{array}{c}(2) \\
\text { All } \\
\text { Downgrades }\end{array}$ & $\begin{array}{c}(3) \\
\text { Investment to } \\
\text { Non-Investment }\end{array}$ & $\begin{array}{c}(4) \\
\text { Investment to } \\
\text { Non-Investment }\end{array}$ & $\begin{array}{c}\text { (5) } \\
\text { AAA to } \\
\text { Non-Investment } \\
\end{array}$ & $\begin{array}{c}(6) \\
\text { AAA to } \\
\text { Non-Investment }\end{array}$ \\
\hline \multicolumn{7}{|l|}{ Panel A: Coefficient Estimates } \\
\hline P\&C dummy & $\begin{array}{l}0.573 * * * \\
(0.124)\end{array}$ & $\begin{array}{c}0.491 * * * \\
(0.130)\end{array}$ & $\begin{array}{c}0.548 * * * \\
(0.155)\end{array}$ & $\begin{array}{c}0.438 * * * \\
(0.165)\end{array}$ & $\begin{array}{c}0.830 * * * \\
(0.222)\end{array}$ & $\begin{array}{c}0.746 * * * \\
(0.234)\end{array}$ \\
\hline Revalue dummy & & $\begin{array}{l}0.342 * * \\
(0.148)\end{array}$ & & $\begin{array}{c}0.588 * * * \\
(0.216)\end{array}$ & & $\begin{array}{c}0.840 * * \\
(0.374)\end{array}$ \\
\hline $\ln$ (maturity) & & $\begin{array}{c}0.074 \\
(0.111)\end{array}$ & & $\begin{array}{l}-0.288 \\
(0.270)\end{array}$ & & $\begin{array}{c}-0.987 * * \\
(0.386)\end{array}$ \\
\hline $\ln ($ issue size) & & $\begin{array}{c}0.001 \\
(0.036)\end{array}$ & & $\begin{array}{c}0.058 \\
(0.042)\end{array}$ & & $\begin{array}{c}0.187 * * * \\
(0.067)\end{array}$ \\
\hline $\begin{array}{l}\text { Rating group (before downgrade) } \\
\text { fixed effects }\end{array}$ & YES & YES & YES & YES & NO & NO \\
\hline State fixed effects & YES & YES & YES & YES & YES & YES \\
\hline Year fixed effects & YES & YES & YES & YES & YES & YES \\
\hline Observations & 21,865 & 20,978 & 6,691 & 6,354 & 2,487 & 2,357 \\
\hline Pseudo R-squared & 0.092 & 0.095 & 0.120 & 0.124 & 0.129 & 0.138 \\
\hline \multicolumn{7}{|l|}{ Panel B: Marginal Effects } \\
\hline $\begin{array}{l}\text { P\&C dummy } \\
\text { Revalue dummy }\end{array}$ & $0.038 * * *$ & $\begin{array}{c}0.033^{* * *} \\
0.023^{* *}\end{array}$ & $0.041^{* * *}$ & $\begin{array}{l}0.033 * * \\
0.049 * *\end{array}$ & $0.064 * * *$ & $\begin{array}{c}0.058^{* * *} \\
0.078^{*}\end{array}$ \\
\hline
\end{tabular}




\section{Table 8: Gains Trading and Probability of Selling Corporate Bonds}

This table reports logit estimates for the effects of unrealized gain on the probability that an insurance company will sell a bond during (i) non-crisis and (ii) crisis periods. The dependent variable is a dummy that equals one if the insurance company holding the bond at the beginning of the quarter sells the bond during the quarter, and zero otherwise. Panel A reports the coefficient estimates. Panel B reports the effects of moving from the 25th to 75th percentiles of unrealized gains, evaluated for (i) the crisis vs. non-crisis periods, (ii) the insurance companies in the top quartile of exposure to ABS not revalued at the previous year-end, and (iii) the insurance companies in the bottom quartile of RBC ratio. Panel C reports the effects of (i) moving from the 25th to 75th percentiles for each continuous control variable and (ii) moving from 0 to 1 for each dummy variable. All other variables are held at the sample means. Standard errors, clustered by insurance company, are in parentheses. *, **, and $* * *$ refer to statistical significance at $10 \%$, 5\%, and $1 \%$ levels. Variable definitions are in Appendix A.

Panel A: Coefficient Estimates

\begin{tabular}{|c|c|c|c|c|c|c|c|c|c|c|c|c|}
\hline & \multicolumn{6}{|c|}{ Life } & \multicolumn{6}{|c|}{ Property and Casualty } \\
\hline & $(1)$ & $(2)$ & $(3)$ & $(4)$ & (5) & $(6)$ & $(7)$ & $(8)$ & (9) & $(10)$ & $(11)$ & $(12)$ \\
\hline & Crisis & Crisis & Non-Crisis & Non-Crisis & All & All & Crisis & Crisis & Non-Crisis & Non-Crisis & All & All \\
\hline \multicolumn{13}{|l|}{$\underline{\text { Main variables }}$} \\
\hline (1) Unrealized gain percentile & $\begin{array}{l}0.191 * \\
(0.109)\end{array}$ & $\begin{array}{l}0.202^{*} \\
(0.104)\end{array}$ & $\begin{array}{c}-0.433^{* * *} \\
(0.077)\end{array}$ & $\begin{array}{c}-0.462^{* * *} \\
(0.077)\end{array}$ & $\begin{array}{c}-0.451^{* * *} \\
(0.079)\end{array}$ & $\begin{array}{c}-0.468^{* * *} \\
(0.079)\end{array}$ & $\begin{array}{c}-0.318^{* * *} \\
(0.106)\end{array}$ & $\begin{array}{c}-0.289 * * * \\
(0.095)\end{array}$ & $\begin{array}{c}-0.077 \\
(0.063)\end{array}$ & $\begin{array}{c}-0.081 \\
(0.063)\end{array}$ & $\begin{array}{c}-0.070 \\
(0.063)\end{array}$ & $\begin{array}{c}-0.068 \\
(0.062)\end{array}$ \\
\hline (2) High ABS exposure dummy & $\begin{array}{l}0.237^{*} \\
(0.132)\end{array}$ & $\begin{array}{c}0.311^{* *} \\
(0.145)\end{array}$ & $\begin{array}{c}0.362 * * * \\
(0.085)\end{array}$ & $\begin{array}{c}0.287 * * * \\
(0.086)\end{array}$ & $\begin{array}{c}0.345^{* * * *} \\
(0.084)\end{array}$ & $\begin{array}{c}0.285^{* * *} \\
(0.085)\end{array}$ & $\begin{array}{c}0.194 * * \\
(0.085)\end{array}$ & $\begin{array}{c}0.213^{* * * *} \\
(0.079)\end{array}$ & $\begin{array}{c}0.220 * * * \\
(0.073)\end{array}$ & $\begin{array}{c}0.241^{* * *} \\
(0.074)\end{array}$ & $\begin{array}{c}0.212 * * * \\
(0.074)\end{array}$ & $\begin{array}{c}0.244 * * * \\
(0.074)\end{array}$ \\
\hline$(1) \times(2)$ & $\begin{array}{c}0.055 \\
(0.155)\end{array}$ & $\begin{array}{c}0.007 \\
(0.147)\end{array}$ & $\begin{array}{c}-0.296 * * \\
(0.123)\end{array}$ & $\begin{array}{c}-0.285^{* *} \\
(0.126)\end{array}$ & $\begin{array}{c}-0.279 * * \\
(0.125)\end{array}$ & $\begin{array}{c}-0.277^{* *} \\
(0.128)\end{array}$ & $\begin{array}{c}0.390^{* *} \\
(0.156)\end{array}$ & $\begin{array}{c}0.309 * * \\
(0.151)\end{array}$ & $\begin{array}{c}0.032 \\
(0.121)\end{array}$ & $\begin{array}{c}0.050 \\
(0.109)\end{array}$ & $\begin{array}{c}0.034 \\
(0.122)\end{array}$ & $\begin{array}{c}0.030 \\
(0.111)\end{array}$ \\
\hline (3) Low RBC ratio dummy & $\begin{array}{c}0.361^{* *} \\
(0.169)\end{array}$ & $\begin{array}{c}0.366^{* *} \\
(0.164)\end{array}$ & $\begin{array}{c}0.064 \\
(0.079)\end{array}$ & $\begin{array}{c}-0.053 \\
(0.107)\end{array}$ & $\begin{array}{c}0.064 \\
(0.078)\end{array}$ & $\begin{array}{c}-0.015 \\
(0.099)\end{array}$ & $\begin{array}{c}-0.011 \\
(0.094)\end{array}$ & $\begin{array}{l}-0.028 \\
(0.094)\end{array}$ & $\begin{array}{c}0.077 \\
(0.081)\end{array}$ & $\begin{array}{c}0.062 \\
(0.079)\end{array}$ & $\begin{array}{c}0.081 \\
(0.081)\end{array}$ & $\begin{array}{c}0.067 \\
(0.077)\end{array}$ \\
\hline (1) x (3) & $\begin{array}{c}-0.165 \\
(0.289)\end{array}$ & $\begin{array}{c}-0.254 \\
(0.262)\end{array}$ & $\begin{array}{c}0.333 * * \\
(0.165)\end{array}$ & $\begin{array}{c}0.431 * * \\
(0.171)\end{array}$ & $\begin{array}{c}0.379 * * \\
(0.166)\end{array}$ & $\begin{array}{c}0.453^{* * *} \\
(0.171)\end{array}$ & $\begin{array}{c}0.181 \\
(0.172)\end{array}$ & $\begin{array}{c}0.158 \\
(0.176)\end{array}$ & $\begin{array}{c}0.150 \\
(0.127)\end{array}$ & $\begin{array}{l}0.212 * \\
(0.128)\end{array}$ & $\begin{array}{c}0.164 \\
(0.125)\end{array}$ & $\begin{array}{c}0.206 \\
(0.126)\end{array}$ \\
\hline (1) $\mathrm{x}(2) \mathrm{x}(3)$ & $\begin{array}{l}0.394^{*} \\
(0.231)\end{array}$ & $\begin{array}{c}0.597 * * \\
(0.294)\end{array}$ & $\begin{array}{c}-0.027 \\
(0.296)\end{array}$ & $\begin{array}{l}-0.055 \\
(0.292)\end{array}$ & $\begin{array}{c}-0.104 \\
(0.286)\end{array}$ & $\begin{array}{c}-0.071 \\
(0.301)\end{array}$ & $\begin{array}{l}-0.437 \\
(0.319)\end{array}$ & $\begin{array}{c}-0.313 \\
(0.327)\end{array}$ & $\begin{array}{c}-0.195 \\
(0.205)\end{array}$ & $\begin{array}{c}-0.300 \\
(0.184)\end{array}$ & $\begin{array}{c}-0.202 \\
(0.202)\end{array}$ & $\begin{array}{l}-0.266 \\
(0.192)\end{array}$ \\
\hline (4) Revalue dummy & $\begin{array}{c}0.621 * * * \\
(0.118)\end{array}$ & $\begin{array}{c}0.646 * * * \\
(0.122)\end{array}$ & $\begin{array}{c}0.509 * * * \\
(0.092)\end{array}$ & $\begin{array}{c}0.652 * * * \\
(0.173)\end{array}$ & $\begin{array}{c}0.554 * * * \\
(0.084)\end{array}$ & $\begin{array}{c}0.665 * * * \\
(0.158)\end{array}$ & $\begin{array}{c}0.212 * * * \\
(0.075)\end{array}$ & $\begin{array}{c}0.181^{* *} \\
(0.075)\end{array}$ & $\begin{array}{c}0.256 * * * \\
(0.063)\end{array}$ & $\begin{array}{c}0.264 * * * \\
(0.058)\end{array}$ & $\begin{array}{c}0.250 * * * \\
(0.064)\end{array}$ & $\begin{array}{c}0.263^{* * *} \\
(0.057)\end{array}$ \\
\hline Crisis dummy & & & & & $\begin{array}{l}-0.611 * * * \\
(0.086)\end{array}$ & & & & & & $\begin{array}{c}-0.082 \\
(0.071)\end{array}$ & \\
\hline Crisis dummy $\mathrm{x}(1)$ & & & & & $\begin{array}{c}0.735^{* * *} \\
(0.120)\end{array}$ & $\begin{array}{c}0.732 * * * \\
(0.113)\end{array}$ & & & & & $\begin{array}{c}-0.221^{* *} \\
(0.105)\end{array}$ & $\begin{array}{c}-0.203 * * \\
(0.103)\end{array}$ \\
\hline Crisis dummy $\mathrm{x}(2)$ & & & & & $\begin{array}{c}-0.082 \\
(0.122)\end{array}$ & $\begin{array}{c}0.001 \\
(0.115)\end{array}$ & & & & & $\begin{array}{c}-0.044 \\
(0.096)\end{array}$ & $\begin{array}{l}-0.063 \\
(0.095)\end{array}$ \\
\hline Crisis dummy $\mathrm{x}$ (1) x (2) & & & & & $\begin{array}{c}0.293 \\
(0.188)\end{array}$ & $\begin{array}{c}0.283 \\
(0.180)\end{array}$ & & & & & $\begin{array}{c}0.389 * * \\
(0.170)\end{array}$ & $\begin{array}{c}0.347^{* *} \\
(0.166)\end{array}$ \\
\hline Crisis dummy x (3) & & & & & $\begin{array}{c}0.290^{*} \\
(0.176)\end{array}$ & $\begin{array}{c}0.275^{*} \\
(0.165)\end{array}$ & & & & & $\begin{array}{l}-0.076 \\
(0.103)\end{array}$ & $\begin{array}{l}-0.115 \\
(0.104)\end{array}$ \\
\hline Crisis dummy x (1 ) x (3) & & & & & $\begin{array}{c}-0.560 * \\
(0.300)\end{array}$ & $\begin{array}{c}-0.627 * * \\
(0.274)\end{array}$ & & & & & $\begin{array}{c}0.026 \\
(0.203)\end{array}$ & $\begin{array}{l}-0.013 \\
(0.207)\end{array}$ \\
\hline
\end{tabular}




\begin{tabular}{|c|c|c|c|c|c|c|c|c|c|c|c|c|}
\hline & \multicolumn{6}{|c|}{ Life Firms } & \multicolumn{6}{|c|}{ Property and Casualty Firms } \\
\hline & $(1)$ & $(2)$ & (3) & (4) & $(5)$ & $(6)$ & $(7)$ & $(8)$ & (9) & $(10)$ & $(11)$ & $(12)$ \\
\hline & Crisis & Crisis & Non-Crisis & Non-Crisis & All & All & Crisis & Crisis & Non-Crisis & Non-Crisis & All & All \\
\hline Crisis dummy $\mathrm{x}(1) \mathrm{x}(2) \mathrm{x}(3)$ & & & & & $\begin{array}{l}0.510^{*} \\
(0.305)\end{array}$ & $\begin{array}{c}0.502 * \\
(0.300)\end{array}$ & & & & & $\begin{array}{c}-0.263 \\
(0.338)\end{array}$ & $\begin{array}{c}-0.158 \\
(0.340)\end{array}$ \\
\hline Crisis dummy x (4) & & & & & $\begin{array}{c}0.174^{*} \\
(0.105)\end{array}$ & $\begin{array}{c}0.041 \\
(0.161)\end{array}$ & & & & & $\begin{array}{c}-0.064 \\
(0.094)\end{array}$ & $\begin{array}{c}-0.085 \\
(0.103)\end{array}$ \\
\hline \multicolumn{13}{|l|}{$\underline{\text { Bond control variables }}$} \\
\hline ln(bond age) & $\begin{array}{c}-0.209 * * * \\
(0.029)\end{array}$ & $\begin{array}{c}-0.190 * * * \\
(0.029)\end{array}$ & $\begin{array}{c}-0.212^{* * *} \\
(0.025)\end{array}$ & $\begin{array}{c}-0.201 * * * \\
(0.024)\end{array}$ & $\begin{array}{c}-0.234 * * * \\
(0.023)\end{array}$ & $\begin{array}{c}-0.193 * * * \\
(0.023)\end{array}$ & $\begin{array}{c}-0.180 * * * \\
(0.032)\end{array}$ & $\begin{array}{c}-0.179 * * * \\
(0.030)\end{array}$ & $\begin{array}{c}-0.189 * * * \\
(0.023)\end{array}$ & $\begin{array}{c}-0.185^{* * *} \\
(0.023)\end{array}$ & $\begin{array}{c}-0.181 * * * \\
(0.023)\end{array}$ & $\begin{array}{c}-0.177 * * * \\
(0.021)\end{array}$ \\
\hline $\ln$ (maturity) & $\begin{array}{c}-0.319 * * * \\
(0.036)\end{array}$ & $\begin{array}{c}-0.324 * * * \\
(0.036)\end{array}$ & $\begin{array}{c}-0.130 * * * \\
(0.024)\end{array}$ & $\begin{array}{c}-0.132 * * * \\
(0.023)\end{array}$ & $\begin{array}{c}-0.197 * * * \\
(0.023)\end{array}$ & $\begin{array}{c}-0.195 * * * \\
(0.022)\end{array}$ & $\begin{array}{c}-0.105^{* * * *} \\
(0.033)\end{array}$ & $\begin{array}{c}-0.114 * * * \\
(0.031)\end{array}$ & $\begin{array}{l}0.046^{*} \\
(0.027)\end{array}$ & $\begin{array}{l}0.045^{*} \\
(0.026)\end{array}$ & $\begin{array}{l}-0.002 \\
(0.022)\end{array}$ & $\begin{array}{l}-0.004 \\
(0.021)\end{array}$ \\
\hline $\ln ($ issue size) & $\begin{array}{c}0.362 * * * \\
(0.017)\end{array}$ & $\begin{array}{c}0.355^{* * *} \\
(0.015)\end{array}$ & $\begin{array}{c}0.312^{* * *} \\
(0.012)\end{array}$ & $\begin{array}{c}0.299 * * * \\
(0.013)\end{array}$ & $\begin{array}{c}0.317 * * * \\
(0.012)\end{array}$ & $\begin{array}{c}0.322 * * * \\
(0.011)\end{array}$ & $\begin{array}{c}0.242 * * * \\
(0.015)\end{array}$ & $\begin{array}{c}0.236 * * * \\
(0.015)\end{array}$ & $\begin{array}{c}0.231^{* * * *} \\
(0.012)\end{array}$ & $\begin{array}{c}0.223 * * * \\
(0.012)\end{array}$ & $\begin{array}{c}0.232 * * * \\
(0.011)\end{array}$ & $\begin{array}{c}0.228 * * * \\
(0.011)\end{array}$ \\
\hline Bankruptcy dummy & $\begin{array}{c}1.857 * * * \\
(0.107)\end{array}$ & $\begin{array}{c}1.891^{* * *} \\
(0.110)\end{array}$ & $\begin{array}{c}2.312^{* * *} \\
(0.156)\end{array}$ & $\begin{array}{c}2.381^{* * *} \\
(0.161)\end{array}$ & $\begin{array}{c}1.924 * * * \\
(0.086)\end{array}$ & $\begin{array}{c}1.992 * * * \\
(0.091)\end{array}$ & $\begin{array}{c}1.534^{* * * *} \\
(0.279)\end{array}$ & $\begin{array}{c}1.560^{* * *} \\
(0.281)\end{array}$ & $\begin{array}{c}1.961^{* * * *} \\
(0.296)\end{array}$ & $\begin{array}{c}1.940 * * * \\
(0.315)\end{array}$ & $\begin{array}{c}1.531^{* * *} \\
(0.234)\end{array}$ & $\begin{array}{c}1.610^{* * *} \\
(0.246)\end{array}$ \\
\hline Downgrade dummy & $\begin{array}{c}1.021^{* * *} \\
(0.082)\end{array}$ & $\begin{array}{c}1.024^{* * *} \\
(0.081)\end{array}$ & $\begin{array}{c}1.456^{* * *} \\
(0.049)\end{array}$ & $\begin{array}{c}1.464^{* * *} \\
(0.050)\end{array}$ & $\begin{array}{c}1.293^{* * *} \\
(0.046)\end{array}$ & $\begin{array}{c}1.254^{* * *} \\
(0.049)\end{array}$ & $\begin{array}{c}1.491^{* * *} \\
(0.079)\end{array}$ & $\begin{array}{c}1.502^{* * *} \\
(0.080)\end{array}$ & $\begin{array}{c}1.496^{* * *} \\
(0.073)\end{array}$ & $\begin{array}{c}1.529 * * * \\
(0.073)\end{array}$ & $\begin{array}{c}1.413^{* * *} \\
(0.058)\end{array}$ & $\begin{array}{c}1.491^{* * *} \\
(0.059)\end{array}$ \\
\hline \multicolumn{13}{|l|}{ Insurance control variables } \\
\hline ln(capital and surplus) & $\begin{array}{c}0.019 \\
(0.036)\end{array}$ & $\begin{array}{c}0.016 \\
(0.037)\end{array}$ & $\begin{array}{c}0.024 \\
(0.029)\end{array}$ & $\begin{array}{c}0.001 \\
(0.026)\end{array}$ & $\begin{array}{c}0.020 \\
(0.027)\end{array}$ & $\begin{array}{c}0.009 \\
(0.025)\end{array}$ & $\begin{array}{c}-0.002 \\
(0.029)\end{array}$ & $\begin{array}{c}0.026 \\
(0.033)\end{array}$ & $\begin{array}{c}0.012 \\
(0.021)\end{array}$ & $\begin{array}{c}0.020 \\
(0.020)\end{array}$ & $\begin{array}{c}0.014 \\
(0.020)\end{array}$ & $\begin{array}{c}0.028 \\
(0.020)\end{array}$ \\
\hline \% risky assets & $\begin{array}{c}0.010 \\
(0.007)\end{array}$ & $\begin{array}{c}0.008 \\
(0.007)\end{array}$ & $\begin{array}{c}0.009 * * \\
(0.004)\end{array}$ & $\begin{array}{c}0.008 * * \\
(0.004)\end{array}$ & $\begin{array}{l}0.009 * \\
(0.005)\end{array}$ & $\begin{array}{c}0.010^{* *} \\
(0.004)\end{array}$ & $\begin{array}{c}0.004 \\
(0.003)\end{array}$ & $\begin{array}{c}0.004 \\
(0.003)\end{array}$ & $\begin{array}{c}-0.000 \\
(0.000)\end{array}$ & $\begin{array}{l}-0.000 \\
(0.000)\end{array}$ & $\begin{array}{l}-0.000 \\
(0.000)\end{array}$ & $\begin{array}{l}-0.000 \\
(0.000)\end{array}$ \\
\hline Leverage & $\begin{array}{l}1.580^{*} \\
(0.904)\end{array}$ & $\begin{array}{c}1.079 \\
(0.812)\end{array}$ & $\begin{array}{l}0.893^{*} \\
(0.457)\end{array}$ & $\begin{array}{l}0.753^{*} \\
(0.425)\end{array}$ & $\begin{array}{l}1.240^{* *} \\
(0.616)\end{array}$ & $\begin{array}{c}0.871 \\
(0.533)\end{array}$ & $\begin{array}{c}0.281 \\
(0.453)\end{array}$ & $\begin{array}{c}0.031 \\
(0.419)\end{array}$ & $\begin{array}{c}0.013 \\
(0.323)\end{array}$ & $\begin{array}{l}-0.049 \\
(0.306)\end{array}$ & $\begin{array}{c}0.030 \\
(0.300)\end{array}$ & $\begin{array}{l}-0.059 \\
(0.291)\end{array}$ \\
\hline ROE & $\begin{array}{c}0.070 \\
(0.185)\end{array}$ & $\begin{array}{c}-0.147 \\
(0.175)\end{array}$ & $\begin{array}{c}-0.046 \\
(0.121)\end{array}$ & $\begin{array}{c}-0.166 \\
(0.119)\end{array}$ & $\begin{array}{c}0.048 \\
(0.114)\end{array}$ & $\begin{array}{c}-0.146 \\
(0.113)\end{array}$ & $\begin{array}{c}0.027 \\
(0.459)\end{array}$ & $\begin{array}{l}-0.006 \\
(0.475)\end{array}$ & $\begin{array}{c}-0.386 \\
(0.250)\end{array}$ & $\begin{array}{c}-0.457^{*} \\
(0.270)\end{array}$ & $\begin{array}{c}-0.276 \\
(0.236)\end{array}$ & $\begin{array}{c}-0.368 \\
(0.250)\end{array}$ \\
\hline Rating group fixed effects & YES & YES & YES & YES & YES & YES & YES & YES & YES & YES & YES & YES \\
\hline State fixed effects & NO & YES & NO & YES & NO & YES & NO & YES & NO & YES & NO & YES \\
\hline Quarter fixed effects & YES & YES & YES & YES & NO & YES & YES & YES & YES & YES & NO & YES \\
\hline Observations & $1,018,874$ & $1,018,874$ & $1,478,908$ & $1,478,908$ & $2,497,782$ & $2,497,782$ & 526,873 & 526,873 & 774,144 & 774,144 & $1,301,017$ & $1,301,017$ \\
\hline Pseudo R-squared & 0.060 & 0.070 & 0.039 & 0.050 & 0.043 & 0.055 & 0.043 & 0.052 & 0.037 & 0.043 & 0.034 & 0.044 \\
\hline
\end{tabular}


Table 8, cont'd: Gains Trading and Probability of Selling Corporate Bonds

Panel B: Effects of Moving from the 25th to 75th Percentiles of Unrealized Gain

\begin{tabular}{|c|c|c|c|c|c|c|}
\hline & \multicolumn{3}{|c|}{$\begin{array}{c}\text { Life } \\
(\text { Mean Selling Probability }=0.042)\end{array}$} & \multicolumn{3}{|c|}{$\begin{array}{c}\text { Property and Casualty } \\
(\text { Mean Selling Probability }=0.054)\end{array}$} \\
\hline & Non-Crisis & Crisis & Difference & Non-Crisis & Crisis & Difference \\
\hline \multicolumn{7}{|l|}{ Models (5) and (11) } \\
\hline $\begin{array}{l}\text { High ABS exposure dummy }=0 \\
\text { and Low RBC ratio dummy }=0\end{array}$ & $-0.007 * * *$ & $0.004^{* *}$ & $0.011^{* * *}$ & -0.002 & $-0.005^{* *}$ & -0.004 \\
\hline $\begin{array}{l}\text { High ABS exposure dummy }=1 \\
\text { and Low RBC ratio dummy }=1\end{array}$ & $-0.010 * * *$ & $0.013^{* * *}$ & $0.023 * * *$ & -0.002 & -0.003 & -0.001 \\
\hline \multicolumn{7}{|l|}{ Models (6) and (12) } \\
\hline $\begin{array}{l}\text { High ABS exposure dummy }=0 \\
\text { and Low RBC ratio dummy }=0\end{array}$ & $-0.006 * * *$ & $0.005^{* *}$ & $0.010^{* * *}$ & -0.001 & $-0.005^{* *}$ & -0.004 \\
\hline $\begin{array}{l}\text { High ABS exposure dummy }=1 \\
\text { and Low RBC ratio dummy }=1\end{array}$ & $-0.006^{* * *}$ & $0.017 * * *$ & $0.023 * * *$ & -0.003 & -0.002 & 0.000 \\
\hline
\end{tabular}




\section{Table 8, cont'd: Gains Trading and Probability of Selling Corporate Bonds}

Panel C: Effects of Moving from the 25th to 75th Percentiles of Continuous Control Variables and from 0 to 1 of Dummy Control Variables

\begin{tabular}{|c|c|c|c|c|c|c|c|c|c|c|c|c|}
\hline & \multicolumn{6}{|c|}{ Life (Mean Selling probability $=0.042$ ) } & \multicolumn{6}{|c|}{ Property and Casualty (Mean Selling Probability $=0.054$ ) } \\
\hline & $(1)$ & $(2)$ & $(3)$ & $(4)$ & $(5)$ & $(6)$ & $(7)$ & $(8)$ & $(9)$ & $(10)$ & $(11)$ & $(12)$ \\
\hline & Crisis & Crisis & Non-Crisis & Non-Crisis & All & All & Crisis & Crisis & Non-Crisis & Non-Crisis & All & All \\
\hline $\begin{array}{l}\text { Revalue dummy } \\
\text { - During non- } \\
\text { crisis }\end{array}$ & & & $0.022 * * *$ & $0.030 * * *$ & $0.025^{* * *}$ & $0.025^{* * *}$ & & & $0.013^{* * *}$ & $0.013^{* * *}$ & $0.013^{* * *}$ & $0.013^{* * *}$ \\
\hline - During crisis & $0.024^{* * *}$ & $0.025 * * *$ & & & $0.030 * * *$ & $0.040 * * *$ & $0.009 * * *$ & $0.008^{* *}$ & & & $0.008^{* *}$ & $0.008^{* *}$ \\
\hline $\ln ($ bond age) & $-0.005^{* * *}$ & $-0.005^{* * *}$ & $-0.007 * * *$ & $-0.006 * * *$ & $-0.007 * * *$ & $-0.006 * * *$ & $-0.007 * * *$ & $-0.006 * * *$ & $-0.008 * * *$ & $-0.007 * * *$ & $-0.007 * * *$ & $-0.007 * * *$ \\
\hline $\ln$ (maturity) & $-0.008 * * *$ & $-0.008 * * *$ & $-0.004 * * *$ & $-0.004 * * *$ & $-0.006 * * *$ & $-0.006 * * *$ & $-0.004 * * *$ & $-0.004 * * *$ & $0.002 *$ & $0.002 *$ & -0.000 & $-0.000 * * *$ \\
\hline ln(issue size) & $0.012^{* * *}$ & $0.011^{* * *}$ & $0.013 * * *$ & $0.012 * * *$ & $0.011^{* * *}$ & $0.011 * * *$ & $0.012^{* * *}$ & $0.011^{* * *}$ & $0.015 * * *$ & $0.014^{* * *}$ & $0.013 * * *$ & $0.012 * * *$ \\
\hline Bankruptcy dummy & $0.134 * * *$ & $0.134^{* * *}$ & $0.236 * * *$ & $0.241^{* * *}$ & $0.161^{* * *}$ & $0.165^{* * *}$ & $0.130 * * *$ & $0.131^{* * *}$ & $0.221 * * *$ & $0.214^{* * *}$ & $0.141^{* * *}$ & $0.150^{* * *}$ \\
\hline Downgrade dummy & $0.048 * * *$ & $0.046^{* * *}$ & $0.100^{* * *}$ & $0.097 * * *$ & $0.079 * * *$ & $0.072 * * *$ & $0.120 * * *$ & $0.119 * * *$ & $0.137 * * *$ & $0.140 * * *$ & $0.121^{* * *}$ & $0.129 * * *$ \\
\hline ln(capital and surplus) & 0.001 & 0.001 & 0.002 & 0.000 & 0.002 & 0.001 & -0.000 & 0.003 & 0.002 & 0.003 & 0.002 & 0.004 \\
\hline \% risky assets & 0.003 & 0.002 & $0.003^{* *}$ & $0.003^{* *}$ & $0.003^{* *}$ & $0.003^{* *}$ & 0.004 & 0.004 & -0.000 & -0.000 & -0.000 & -0.000 \\
\hline Leverage & $0.003^{*}$ & 0.002 & $0.002 *$ & $0.001 *$ & $0.002 * *$ & 0.002 & 0.002 & 0.000 & 0.000 & -0.000 & 0.000 & -0.000 \\
\hline ROE & 0.000 & -0.000 & -0.000 & -0.000 & 0.000 & -0.001 & 0.000 & -0.000 & -0.002 & $-0.002 *$ & -0.001 & -0.002 \\
\hline
\end{tabular}




\section{Table 9: Trade Price Impact of Gains Trading on Corporate Bonds}

This table reports coefficients of regressions of relative sale prices on estimated gains-trading selling pressure faced by insurance companies. For each sale transaction, relative sale price is calculated as the logged ratio of an insurance company's sale price over the median market trade price for the bond during the week (from TRACE). The sample includes only (i) the relative sale prices within the 1st and 99th percentiles and (ii) the weeks in which each bond trades at least 3 times. Gains-trading selling pressure is measured as the incremental effect of unrealized gain on predicted selling probability of an insurance firm's position in the bond during the applicable calendar quarter. The incremental effect of unrealized gain on selling probability is the change in predicted probability as the unrealized gain percentile increases from 0.5 to the actual value, under the logit model (2) in Table 8, estimated separately for each calendar quarter. Standard errors, clustered by bond issuer level, are in parentheses. * ,**, and *** refer to statistical significance at 10\%, 5\%, and 1\% levels. Variable definitions are in Appendixes A.

\begin{tabular}{|c|c|c|c|c|c|c|}
\hline & \multicolumn{3}{|c|}{ Life } & \multicolumn{3}{|c|}{ Property and Casualty } \\
\hline & $(1)$ & $(2)$ & (3) & $(4)$ & $(5)$ & $(6)$ \\
\hline \multicolumn{7}{|l|}{ Main variables } \\
\hline Crisis dummy & $\begin{array}{c}-0.005^{* * *} \\
(0.001)\end{array}$ & $\begin{array}{c}-0.003^{* * *} \\
(0.001)\end{array}$ & & $\begin{array}{l}-0.003 * \\
(0.002)\end{array}$ & $\begin{array}{c}-0.003^{*} \\
(0.002)\end{array}$ & \\
\hline Gains-trading selling pressure & & $\begin{array}{c}-0.019 \\
(0.020)\end{array}$ & $\begin{array}{l}-0.012 \\
(0.022)\end{array}$ & & $\begin{array}{c}0.040 \\
(0.025)\end{array}$ & $\begin{array}{c}0.037 \\
(0.027)\end{array}$ \\
\hline Crisis dummy x Gains-trading selling pressure & & $\begin{array}{c}-0.158^{* * *} \\
(0.046)\end{array}$ & $\begin{array}{c}-0.096^{* *} \\
(0.047)\end{array}$ & & $\begin{array}{l}-0.053 \\
(0.045)\end{array}$ & $\begin{array}{l}-0.052 \\
(0.053)\end{array}$ \\
\hline \multicolumn{7}{|l|}{ Bond control variables } \\
\hline $\ln ($ bond age $)$ & $\begin{array}{c}0.001 \\
(0.001)\end{array}$ & $\begin{array}{c}0.001 \\
(0.001)\end{array}$ & $\begin{array}{c}0.000 \\
(0.001)\end{array}$ & $\begin{array}{c}0.001 \\
(0.001)\end{array}$ & $\begin{array}{c}0.001 \\
(0.001)\end{array}$ & $\begin{array}{c}0.001 \\
(0.001)\end{array}$ \\
\hline $\ln$ (maturity) & $\begin{array}{l}0.001 * * \\
(0.000)\end{array}$ & $\begin{array}{c}0.001 \\
(0.000)\end{array}$ & $\begin{array}{l}0.001^{*} \\
(0.000)\end{array}$ & $\begin{array}{c}0.000 \\
(0.001)\end{array}$ & $\begin{array}{c}0.000 \\
(0.001)\end{array}$ & $\begin{array}{c}0.000 \\
(0.001)\end{array}$ \\
\hline $\ln ($ issue size) & $\begin{array}{c}0.000 * * \\
(0.000)\end{array}$ & $\begin{array}{c}0.000^{* *} \\
(0.000)\end{array}$ & $\begin{array}{c}0.000 * * \\
(0.000)\end{array}$ & $\begin{array}{c}0.000 \\
(0.000)\end{array}$ & $\begin{array}{c}0.000 \\
(0.000)\end{array}$ & $\begin{array}{c}0.000 \\
(0.000)\end{array}$ \\
\hline Bankruptcy dummy & $\begin{array}{l}-0.016 \\
(0.020)\end{array}$ & $\begin{array}{l}-0.014 \\
(0.020)\end{array}$ & $\begin{array}{l}-0.014 \\
(0.020)\end{array}$ & $\begin{array}{c}0.024 \\
(0.021)\end{array}$ & $\begin{array}{c}0.024 \\
(0.021)\end{array}$ & $\begin{array}{c}0.017 \\
(0.021)\end{array}$ \\
\hline Downgrade dummy & $\begin{array}{c}-0.015^{* * *} \\
(0.005)\end{array}$ & $\begin{array}{c}-0.016^{* * *} \\
(0.005)\end{array}$ & $\begin{array}{c}-0.017 * * * \\
(0.006)\end{array}$ & $\begin{array}{c}-0.011^{* *} \\
(0.005)\end{array}$ & $\begin{array}{c}-0.011^{* *} \\
(0.005)\end{array}$ & $\begin{array}{c}-0.012^{* *} \\
(0.005)\end{array}$ \\
\hline
\end{tabular}


Cont'd from previous page

\begin{tabular}{|c|c|c|c|c|c|c|}
\hline \multirow{2}{*}{ ont d from previous page } & \multicolumn{3}{|c|}{ Life } & \multicolumn{3}{|c|}{ Property and Casualty } \\
\hline & $(1)$ & $(2)$ & $(3)$ & $(4)$ & $(5)$ & $(6)$ \\
\hline \multicolumn{7}{|l|}{ Insurance control variables } \\
\hline \multirow[t]{2}{*}{$\overline{\mathrm{ABS} \text { exposure }}$} & $0.030 * * *$ & $0.029 * * *$ & 0.017 & $0.040^{* * *}$ & $0.040 * * *$ & $0.046 * * *$ \\
\hline & $(0.010)$ & $(0.010)$ & $(0.011)$ & $(0.012)$ & $(0.012)$ & $(0.012)$ \\
\hline \multirow[t]{2}{*}{$\ln (\mathrm{RBC}$ ratio) } & 0.001 & 0.001 & $0.002^{*}$ & -0.000 & -0.000 & -0.000 \\
\hline & $(0.001)$ & $(0.001)$ & $(0.001)$ & $(0.001)$ & $(0.001)$ & $(0.001)$ \\
\hline ln(capital and surplus) & $\begin{array}{c}-0.002 * * * \\
(0.000)\end{array}$ & $\begin{array}{c}-0.002 * * * \\
(0.000)\end{array}$ & $\begin{array}{c}-0.002 * * * \\
(0.000)\end{array}$ & $\begin{array}{c}-0.002 * * * \\
(0.000)\end{array}$ & $\begin{array}{c}-0.002 * * * \\
(0.000)\end{array}$ & $\begin{array}{c}-0.002 * * * \\
(0.000)\end{array}$ \\
\hline \multirow[t]{2}{*}{$\%$ risky assets } & 0.000 & 0.000 & 0.000 & $0.000 * *$ & $0.000 * *$ & $0.000 * *$ \\
\hline & $(0.000)$ & $(0.000)$ & $(0.000)$ & $(0.000)$ & $(0.000)$ & $(0.000)$ \\
\hline \multirow[t]{2}{*}{ Leverage } & $-0.014 *$ & $-0.012 *$ & -0.013 & -0.005 & -0.005 & -0.005 \\
\hline & $(0.007)$ & $(0.008)$ & $(0.008)$ & $(0.005)$ & $(0.005)$ & $(0.006)$ \\
\hline ROE & $\begin{array}{c}0.001 \\
(0.001)\end{array}$ & $\begin{array}{c}0.001 \\
(0.001)\end{array}$ & $\begin{array}{c}0.000 \\
(0.002)\end{array}$ & $\begin{array}{l}-0.001 \\
(0.003)\end{array}$ & $\begin{array}{l}-0.001 \\
(0.003)\end{array}$ & $\begin{array}{c}-0.002 \\
(0.002)\end{array}$ \\
\hline \multicolumn{7}{|l|}{ Market and transaction control variables } \\
\hline $\ln ($ trade size) & $\begin{array}{c}0.004 * * * \\
(0.001)\end{array}$ & $\begin{array}{c}0.004 * * * \\
(0.001)\end{array}$ & $\begin{array}{c}0.004^{* * *} \\
(0.001)\end{array}$ & $\begin{array}{c}0.002 * * * \\
(0.001)\end{array}$ & $\begin{array}{c}0.002 * * * \\
(0.001)\end{array}$ & $\begin{array}{c}0.002 * * * \\
(0.001)\end{array}$ \\
\hline In(number of sale trades in quarter) & $\begin{array}{c}0.002^{* * *} \\
(0.001)\end{array}$ & $\begin{array}{c}0.002^{* * *} \\
(0.001)\end{array}$ & $\begin{array}{c}0.002 * * * \\
(0.001)\end{array}$ & $\begin{array}{c}0.002^{* * *} \\
(0.001)\end{array}$ & $\begin{array}{c}0.002^{* * *} \\
(0.001)\end{array}$ & $\begin{array}{c}0.002^{* * *} \\
(0.001)\end{array}$ \\
\hline In(median market trade price) & $\begin{array}{c}-0.041 * * * \\
(0.016)\end{array}$ & $\begin{array}{c}-0.042^{* * *} \\
(0.016)\end{array}$ & $\begin{array}{c}-0.040 * * \\
(0.017)\end{array}$ & $\begin{array}{c}-0.013 \\
(0.018)\end{array}$ & $\begin{array}{c}-0.013 \\
(0.018)\end{array}$ & $\begin{array}{l}-0.015 \\
(0.020)\end{array}$ \\
\hline $\ln ($ range of market trade price) & $\begin{array}{c}-0.002 * * \\
(0.001)\end{array}$ & $\begin{array}{c}-0.002 * * \\
(0.001)\end{array}$ & $\begin{array}{l}-0.002^{*} \\
(0.001)\end{array}$ & $\begin{array}{c}-0.001 \\
(0.001)\end{array}$ & $\begin{array}{c}-0.001 \\
(0.001)\end{array}$ & $\begin{array}{l}-0.001 \\
(0.001)\end{array}$ \\
\hline Rating group fixed effects & YES & YES & YES & YES & YES & YES \\
\hline State fixed effects & YES & YES & YES & YES & YES & YES \\
\hline Calendar quarter fixed effects & NO & NO & YES & NO & NO & YES \\
\hline Observations & 79,107 & 79,107 & 79,107 & 43,291 & 43,291 & 43,291 \\
\hline R-squared & 0.034 & 0.035 & 0.038 & 0.013 & 0.013 & 0.018 \\
\hline
\end{tabular}




\section{Table 10: The Impact of Gains Trading on Corporate Bond Return}

This table reports coefficients of regressions of quarterly bond return on average gains-trading selling pressure from insurance companies. To be included in the regression, the bonds must be held by at least 6 life insurers (25th percentile) at the end of previous year. Quarterly bond return is the log of change in price from the last day of the previous quarter to the last day of the current quarter. For each bond in each quarter, gainstrading selling pressure is measured as either the incremental effect of unrealized gain on selling probability or the percentage unrealized gain, (value-weighted or equally-weighted) averaged across all positions of life insurance companies in the bond. The incremental effect of unrealized gain on selling probability is the change in predicted probability as the unrealized gain percentile increases from 0.5 to the actual value, under the logit model (2) in Table 8, estimated separately for each calendar quarter. Treasury return is the return on maturity-matched Treasury bond/note, proxied by the interpolated constant maturity Treasury bond/note from the Fed. Spread return is the maturity- and rating-matched corporate bond index return minus Treasury return. Corporate bond index return is calculated using Bank of America-Merrill Lynch bond index, adjusted for duration difference between the index and the bond of interest. Standard errors, clustered by bond issuer level, are in parentheses. *, **, and *** refer to statistical significance at 10\%, 5\%, and 1\% levels. Variable definitions are in Appendix A.

\begin{tabular}{|c|c|c|c|c|c|c|c|c|}
\hline \multirow[b]{4}{*}{ Gains-trading selling pressure } & \multicolumn{4}{|c|}{ Average Incremental Selling Probability of Unrealized Gain } & \multicolumn{4}{|c|}{ Average Percentage Unrealized Gain } \\
\hline & $(1)$ & $(2)$ & $(3)$ & $(4)$ & (5) & $(6)$ & $(7)$ & $(8)$ \\
\hline & \multicolumn{2}{|c|}{ Equal Weighted } & \multicolumn{2}{|c|}{ Value Weighted } & \multicolumn{2}{|c|}{ Equal Weighted } & \multicolumn{2}{|c|}{ Value Weighted } \\
\hline & $\begin{array}{c}13.878 \\
(10.645)\end{array}$ & $\begin{array}{c}25.632 \\
(18.348)\end{array}$ & $\begin{array}{l}10.069 \\
(8.888)\end{array}$ & $\begin{array}{c}16.469 \\
(15.812)\end{array}$ & $\begin{array}{l}-0.549 \\
(0.702)\end{array}$ & $\begin{array}{l}-0.652 \\
(1.139)\end{array}$ & $\begin{array}{l}-0.507 \\
(0.716)\end{array}$ & $\begin{array}{l}-0.720 \\
(1.243)\end{array}$ \\
\hline $\begin{array}{l}\text { Crisis dummy x } \\
\text { Gains-trading selling pressure }\end{array}$ & $\begin{array}{c}-142.104 * * * \\
(25.484)\end{array}$ & $\begin{array}{c}-156.217^{* * *} \\
(27.838)\end{array}$ & $\begin{array}{c}-117.353^{* * *} \\
(27.410)\end{array}$ & $\begin{array}{l}-129.435^{* * *} \\
(27.906)\end{array}$ & $\begin{array}{c}-8.736 * * * \\
(2.767)\end{array}$ & $\begin{array}{c}-10.956 * * * \\
(3.535)\end{array}$ & $\begin{array}{c}-12.918^{* * *} \\
(1.651)\end{array}$ & $\begin{array}{c}-16.631^{* * *} \\
(1.837)\end{array}$ \\
\hline Treasury return & $\begin{array}{c}0.619 * * * \\
(0.036)\end{array}$ & $\begin{array}{c}0.621^{* * *} \\
(0.036)\end{array}$ & $\begin{array}{c}0.615^{* * *} \\
(0.036)\end{array}$ & $\begin{array}{c}0.617 * * * \\
(0.036)\end{array}$ & $\begin{array}{c}0.593 * * * \\
(0.038)\end{array}$ & $\begin{array}{c}0.595^{* * *} \\
(0.037)\end{array}$ & $\begin{array}{c}0.589 * * * \\
(0.037)\end{array}$ & $\begin{array}{c}0.592 * * * \\
(0.036)\end{array}$ \\
\hline Spread return & $\begin{array}{c}0.577 * * * \\
(0.036)\end{array}$ & $\begin{array}{c}0.578^{* * *} \\
(0.036)\end{array}$ & $\begin{array}{c}0.574 * * * \\
(0.036)\end{array}$ & $\begin{array}{c}0.575^{* * *} \\
(0.035)\end{array}$ & $\begin{array}{c}0.563^{* * *} \\
(0.038)\end{array}$ & $\begin{array}{c}0.561^{* * *} \\
(0.037)\end{array}$ & $\begin{array}{c}0.557 * * * \\
(0.037)\end{array}$ & $\begin{array}{c}0.554^{* * *} \\
(0.036)\end{array}$ \\
\hline $\ln ($ bond age) & $\begin{array}{l}-0.032 \\
(0.057)\end{array}$ & $\begin{array}{c}0.440 * * \\
(0.213)\end{array}$ & $\begin{array}{l}-0.020 \\
(0.055)\end{array}$ & $\begin{array}{l}0.429 * * \\
(0.205)\end{array}$ & $\begin{array}{c}0.040 \\
(0.059)\end{array}$ & $\begin{array}{c}0.003 \\
(0.285)\end{array}$ & $\begin{array}{c}0.086 \\
(0.058)\end{array}$ & $\begin{array}{l}-0.330 \\
(0.245)\end{array}$ \\
\hline $\ln ($ issue size) & $\begin{array}{c}0.005 \\
(0.036)\end{array}$ & & $\begin{array}{l}-0.024 \\
(0.036)\end{array}$ & & $\begin{array}{l}-0.032 \\
(0.043)\end{array}$ & & $\begin{array}{l}-0.014 \\
(0.041)\end{array}$ & \\
\hline $\ln$ (maturity) & $\begin{array}{c}-0.107^{* *} \\
(0.047)\end{array}$ & $\begin{array}{c}0.048 \\
(0.257)\end{array}$ & $\begin{array}{c}-0.104^{* *} \\
(0.047)\end{array}$ & $\begin{array}{c}0.155 \\
(0.248)\end{array}$ & $\begin{array}{c}-0.090^{* *} \\
(0.045)\end{array}$ & $\begin{array}{l}-0.036 \\
(0.275)\end{array}$ & $\begin{array}{c}-0.090^{* *} \\
(0.046)\end{array}$ & $\begin{array}{l}-0.123 \\
(0.272)\end{array}$ \\
\hline Downgrade dummy & $\begin{array}{c}-4.065^{* * *} \\
(1.529)\end{array}$ & $\begin{array}{l}-2.174 \\
(1.605)\end{array}$ & $\begin{array}{c}-4.038^{* * *} \\
(1.529)\end{array}$ & $\begin{array}{l}-2.173 \\
(1.602)\end{array}$ & $\begin{array}{c}-4.393 * * * \\
(1.562)\end{array}$ & $\begin{array}{l}-2.426 \\
(1.605)\end{array}$ & $\begin{array}{c}-4.642^{* * *} \\
(1.572)\end{array}$ & $\begin{array}{l}-2.701^{*} \\
(1.616)\end{array}$ \\
\hline
\end{tabular}




\begin{tabular}{|c|c|c|c|c|c|c|c|c|}
\hline & \multicolumn{4}{|c|}{ Average Incremental Selling Probability of Unrealized Gain } & \multicolumn{4}{|c|}{ Average Percentage Unrealized Gain } \\
\hline & $(1)$ & $(2)$ & (3) & $(4)$ & $(5)$ & $(6)$ & $(7)$ & $(8)$ \\
\hline & \multicolumn{2}{|c|}{ Equal Weighted } & \multicolumn{2}{|c|}{ Value Weighted } & \multicolumn{2}{|c|}{ Equal Weighted } & \multicolumn{2}{|c|}{ Value Weighted } \\
\hline \multirow[t]{2}{*}{ Bankruptcy dummy } & $-12.416^{*}$ & -10.171 & $-12.524^{*}$ & -10.312 & $-13.834 *$ & -12.461 & $-14.041^{*}$ & -12.647 \\
\hline & $(7.384)$ & (7.937) & $(7.315)$ & (7.809) & $(8.019)$ & $(8.592)$ & $(7.983)$ & $(8.575)$ \\
\hline Rating group fixed effects & YES & YES & YES & YES & YES & YES & YES & YES \\
\hline Calendar quarter fixed effects & YES & YES & YES & YES & YES & YES & YES & YES \\
\hline Bond fixed effects & NO & YES & NO & YES & NO & YES & NO & YES \\
\hline Observations & 85,301 & 85,301 & 85,301 & 85,301 & 85,301 & 85,301 & 85,301 & 85,301 \\
\hline R-squared & 0.302 & 0.306 & 0.302 & 0.306 & 0.299 & 0.304 & 0.302 & 0.308 \\
\hline Number of bonds & & 7,882 & & 7,882 & & 7,882 & & 7,882 \\
\hline
\end{tabular}




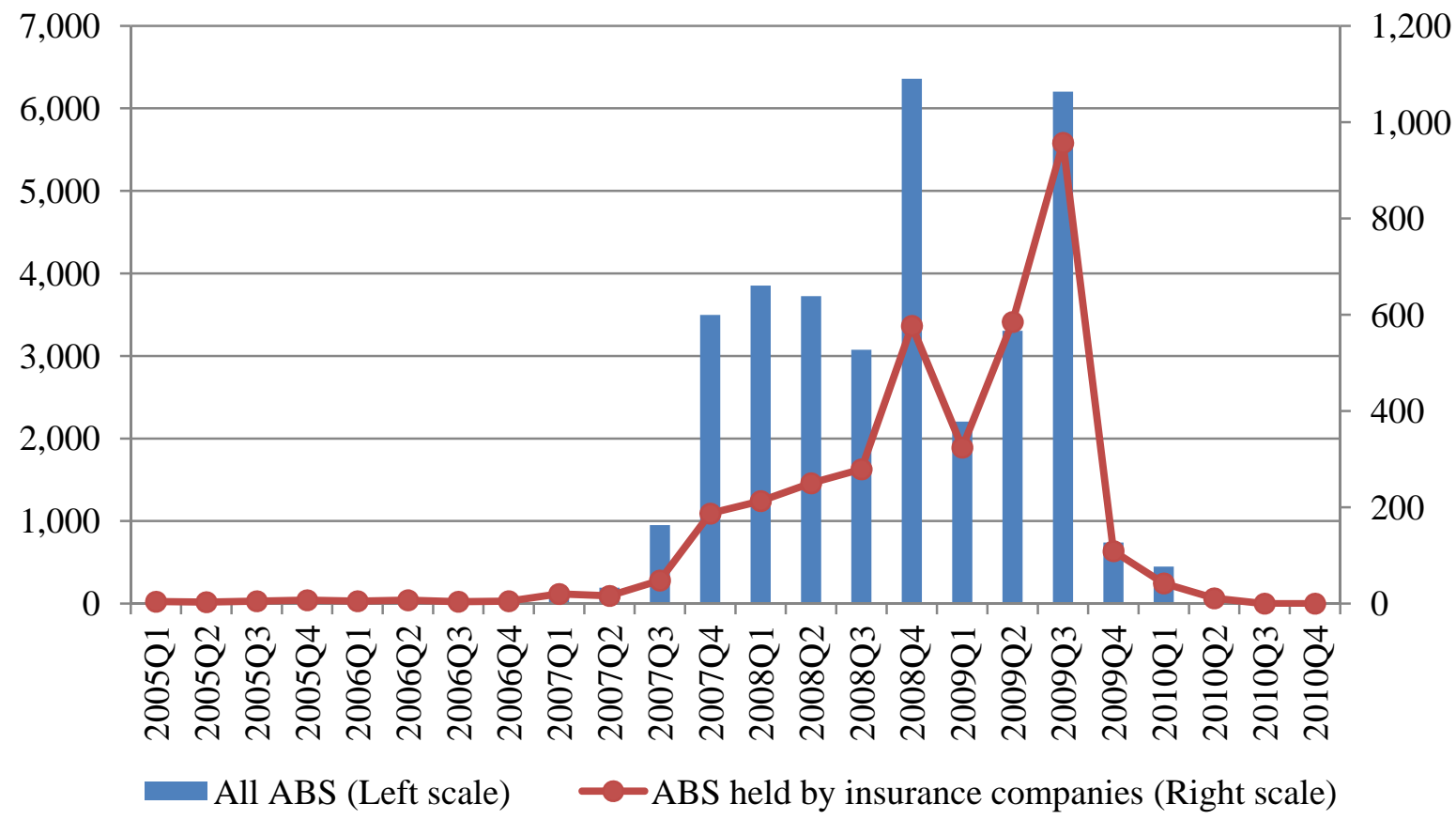

Figure 1: Number of Downgrades of ABS by S\&P from Investment to Non-Investment Grades

This figure presents the number of downgrades of ABS securities from an investment-grade rating to a speculative-grade rating by S\&P on quarterly basis. The bars show the number of all downgraded ABS securities included in S\&P's Ratings IQuerry. The connected dots show the number of downgraded ABS securities that are held by at least one insurance company. 


\section{Panel A: Investment-Grade ABS}

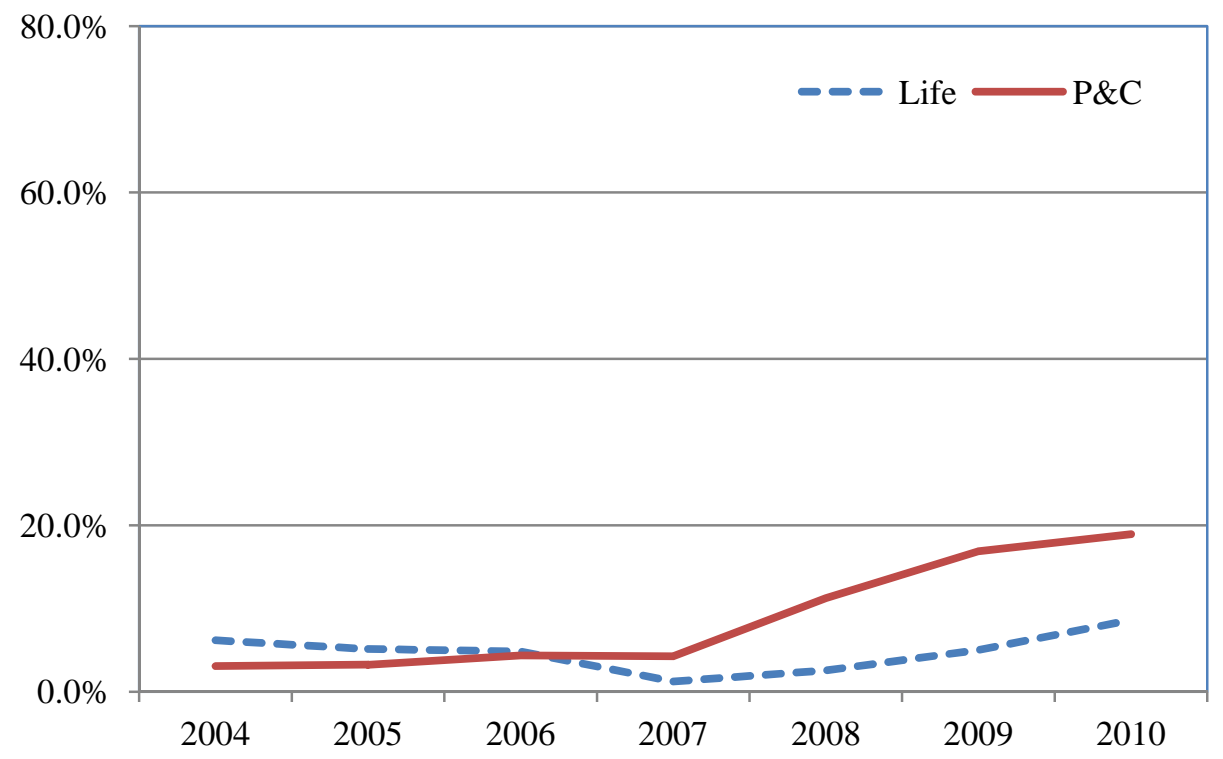

Panel B: Non-Investment-Grade ABS

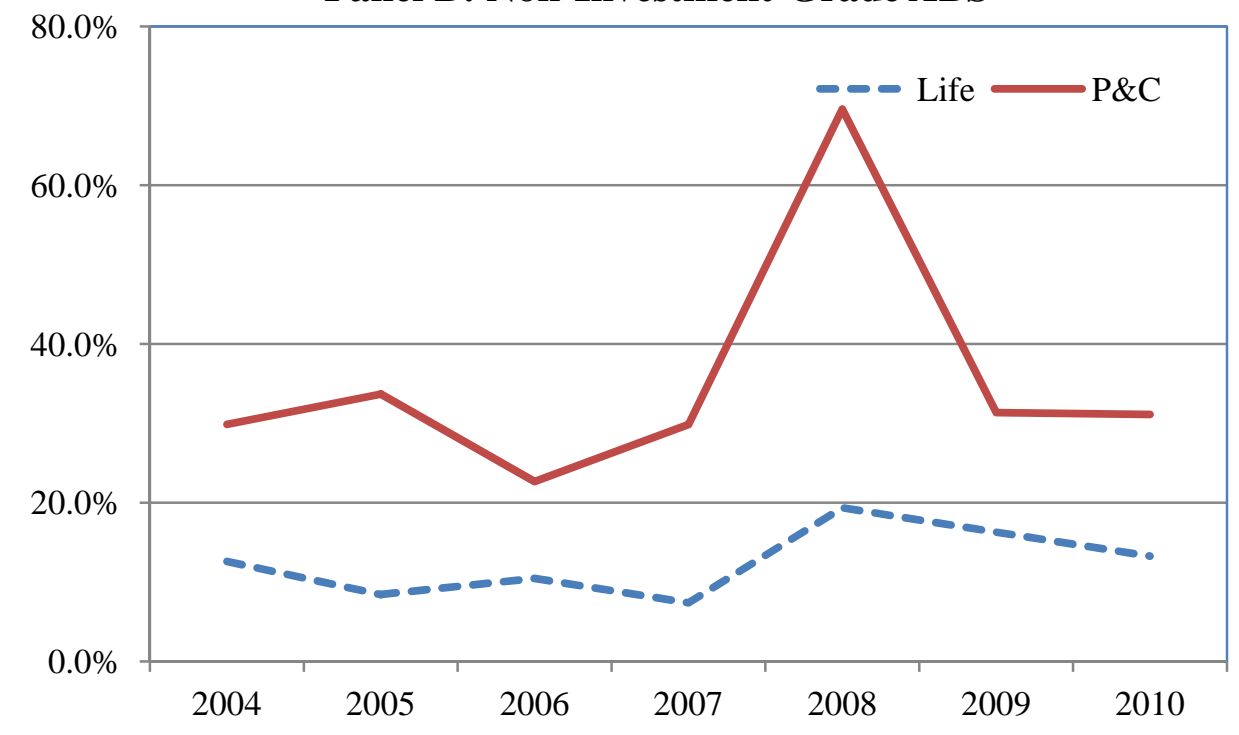

\section{Figure 2: Fraction of ABS Positions Revalued at Year End}

This figure presents the number of ABS positions revalued to the year-end fair value as a percentage of all ABS positions across all life and P\&C companies at the end of 2004-2010. A position is classified as revalued to the year-end fair value if the book-adjusted carrying value equals the reported fair value reported. Panel A is for investment-grade ABS (those rated BBB- and above by S\&P) and Panel B is for non-investment-grade $\mathrm{ABS}$ (those rated $\mathrm{BB}+$ and below including $\mathrm{NR}$ ). 